\title{
Transcriptome exploration of the sex pheromone gland of Lutzomyia longipalpis (Diptera: Psychodidae: Phlebotominae)
}

\author{
Natalia González-Caballero', Jesus G Valenzuela², José MC Ribeiro ${ }^{2}$, Patricia Cuervo ${ }^{3}$ and Reginaldo P Brazil ${ }^{* *}$
}

\begin{abstract}
Background: Molecules involved in pheromone biosynthesis may represent alternative targets for insect population control. This may be particularly useful in managing the reproduction of Lutzomyia longipalpis, the main vector of the protozoan parasite Leishmania infantum in Latin America. Besides the chemical identity of the major components of the L. longipalpis sex pheromone, there is no information regarding the molecular biology behind its production. To understand this process, obtaining information on which genes are expressed in the pheromone gland is essential.
\end{abstract}

Methods: In this study we used a transcriptomic approach to explore the pheromone gland and adjacent abdominal tergites in order to obtain substantial general sequence information. We used a laboratory-reared $L$. longipalpis (one spot, 9-Methyl GermacreneB) population, captured in Lapinha Cave, state of Minas Gerais, Brazil for this analysis.

Results: From a total of 3,547 cDNA clones, 2,502 high quality sequences from the pheromone gland and adjacent tissues were obtained and assembled into 1,387 contigs. Through blast searches of public databases, a group of transcripts encoding proteins potentially involved in the production of terpenoid precursors were identified in the $4^{\text {th }}$ abdominal tergite, the segment containing the pheromone gland. Among them, protein-coding transcripts for four enzymes of the mevalonate pathway such as 3-hydroxyl-3-methyl glutaryl CoA reductase, phosphomevalonate kinase, diphosphomevalonate descarboxylase, and isopentenyl pyrophosphate isomerase were identified. Moreover, transcripts coding for farnesyl diphosphate synthase and $\mathrm{NADP}^{+}$dependent farnesol dehydrogenase were also found in the same tergite. Additionally, genes potentially involved in pheromone transportation were identified from the three abdominal tergites analyzed.

Conclusion: This study constitutes the first transcriptomic analysis exploring the repertoire of genes expressed in the tissue containing the L. longipalpis pheromone gland as well as the flanking tissues. Using a comparative approach, a set of molecules potentially present in the mevalonate pathway emerge as interesting subjects for further study regarding their association to pheromone biosynthesis. The sequences presented here may be used as a reference set for future research on pheromone production or other characteristics of pheromone communication in this insect. Moreover, some matches for transcripts of unknown function may provide fertile ground of an in-depth study of pheromone-gland specific molecules.

Keywords: Lutzomyia longipalpis, Male pheromone gland, Transcriptome, Mevalonate pathway

\footnotetext{
* Correspondence: rpbrazil@ioc.fiocruz.br

'Laboratório de Bioquímica e Fisiologia de Insetos, IOC, FIOCRUZ, Av. Brasil 4365, Manguinhos, Pav. Leônidas Deane, Sala 213, Rio de Janeiro, RJ CEP: 21040-360, Brasil

Full list of author information is available at the end of the article
}

\section{Biomed Central}

(c) 2013 González-Caballero et al.; licensee BioMed Central Ltd. This is an Open Access article distributed under the terms of the Creative Commons Attribution License (http://creativecommons.org/licenses/by/2.0), which permits unrestricted use, distribution, and reproduction in any medium, provided the original work is properly cited. 


\section{Background}

The sandfly Lutzomyia longipalpis (Lutz \& Neiva, 1912) is the principal vector of Leishmania infantum (Protozoa: Kinetoplastida) in the Americas, a protozoan parasite responsible for American visceral leishmaniasis (AVL) [1-3]. L. longipalpis uses male-produced pheromones for mate recognition. Females perceive and respond to a specific chemical signal from distances of a few meters $[4,5]$. Additionally, there is evidence that the same pheromone also produces male aggregation [6]. These attractants are synthesized by specialized gland cells located beneath the cuticle in abdominal segments of adult insects [7]. Recently, a study with L. longipalpis obtained from Lapinha Cave, Minas Gerais, Brazil reported that pheromone biosynthesis started around 12 hours after emergence and increased for 3 days from then on, stabilizing thereafter [8]. Once the pheromone is produced, it is disseminated to the environment through papular structures located in pale abdominal spots [9]. In L. longipalpis populations these pale-spots phenotypes can be found as a single pair (1S) on the fourth abdominal segment, or as two pairs (2S), on both the third and fourth abdominal segments. The lighter-colored appearance of these segments, exposing the pheromone disseminating structure, is generally attributed to the absence of macrotrichias, widely distributed over the rest of the abdominal surface of the insect [10].

Lutzomyia longipalpis is apparently a complex of sibling species ([11], reviewed in [12]), although the number and distribution of potential component species remains to be established [13-15]. Early studies with different $L$. longipalpis populations identified the main chemical components of the pheromone blends belong to the terpene class of compounds [16-18]. Four distinct terpenes have been identified, two of which have been completely characterized to have 16 carbons (homosesquiterpenes) and two compounds having 20 carbons (diterpenes) of unknown stereochemistry. The homosesquiterpenes of the L. longipalpis sex phermone are (1S,3S,7R)-3-methyl-a-himachalene and (S)-9-methylgermacrene-B. In Brazil, these pheromones are produced by insects found in Jacobina, state of Bahia, and Lapinha Cave, state of Minas Gerais, respectively $[17,19]$. Other populations, such as L. longipalpis from Sobral, state of Ceará and Jaíba, state of Minas Gerais, produce two diterpene isomeres: cembrene1 and cembrene2, respectively [20]. A fifth pheromoneproducing L. longipalpis population (chemotype) found in Sobral, state of Ceará, is distinguished for its varying amounts of terpenes, relative to the populations previously mentioned, as well as other morphological differences [16]. These diverse populations make the L. longipalis complex an interesting model for research on genetic regulation, enzymatic components, and pathways of pheromone production.

In addition to the Lutozmyia genus, there has been progress in the chemical communication research of other phlebotomine genera such as Sergentomyia and Phlebotomus [21]. Although terpenes similar to those of the L. longipalpis species complex have been found to be produced in species such as Sergentomyia minuta and Sergentomyia fallax [22], their role in pheromone communication or other biological functions remains unclear. On the other hand, studies have presented behavioral evidence for the presence of sex pheromones in Phlebotomus papatasi, without identifying their pheromone structures [23,24].

Terpene compounds are one of the largest groups of natural products that have significant roles as repellents or attractants to many organisms [25]. They are derived from a five-carbon precursor isopentenyl diphosphate (IPP) and its isomer dimethylallyl diphosphate (DMAPP) [26]. These compounds are produced by a cellular metabolic pathway, the mevalonate route or mevalonate dependent pathway (MAD) [27], which is present in higher eukaryotes and many bacteria. Alternatively, IPP and DMAPP can also be produced through a different pathway, the methylerithritol phosphate pathway (MEP), also known as the deoxysylulose phosphate pathway (DOXP), which operates in many bacteria, plant chloroplast, and some eukaryotic parasites [28].

The MAD route involves a series of enzymatic reactions whose rate-limiting step is the reduction of the 3-hydroxy -3-methylglutaryl-CoA (HMG-CoA) to a mevalonic acid catalyzed by the enzyme 3-hydroxy-3-methylglutaryl-CoA reductase (HMG-R) [29]. Therefore HMG-R is considered the rate-limiting enzyme of this route. In insects, several studies of the mavalonate pathway have been motivated by its role in providing important bioactive molecules such as juvenile hormones [30] and aggregation pheromones (reviewed in [31]).

Following the mevalonate pathway, the two $\mathrm{C}_{5}$ isomeric products (IPP and DMAPP) are condensed into the monoterpe precursor $\left(C_{10}\right)$, geranyl diphosphate (GPP), catalyzed by the geranyl diphosphate synthase (GPPS). Further condensation of the $\mathrm{C}_{5}$ units with the GPP molecule convert into farnesyl diphosphate (FPP) $\left(C_{15}\right)$ and geranylgeranyl pyrophosphate (GGPP) $\left(C_{20}\right)$, the precursors of sesqui- and diterpene compounds among others (reviewed in [32]). These reactions are catalyzed by farnesyl diphosphate synthase (FPPS) and geranyl geranyl diphosphate synthase (GPPS), respectively, also known as short-chain prenyltransferases [33]. By applying molecular methods, these enzymes have been sequenced in several insects [34-38], some of which were directly involved in pheromone production $[39,40]$. Based on this, it is conceivable to hypothesize that pheromone biosynthesis in L. longipalpis involves 
the mevalonate pathway as well as prenyltransferase activity.

Molecular technologies allow the exploration of biosynthetic pathways by recognizing the expression of their enzymatic machineries [41]. This method has been successfully employed in recent studies that have analyzed enzymes in pheromone production of moths $[42,43]$ and diterpene secretion in termites [44]. Additionally, the construction and sequencing of cDNA libraries for L. longipalpis has been used to obtain genetic profiles from whole insects [45] as well as from separate tissues such as salivary glands [46], midgut $[47,48]$ and more recently, the male reproductive organ [49].

Besides the chemical identity of pheromones, there is no information about the molecular basis of pheromone production in $L$. longipalpis. In this respect, the main objective of this study was to identify the genes expressed in the pheromone gland and flanking tissues of one L. longipalpis population and consequently generate the first sequence catalogue for a specialized tissue where the pheromone (S)-9-methylgermacrene- $B$ is produced. For this purpose, we constructed a cDNA library from three abdominal segments, the $3^{\text {rd }}, 4^{\text {th }}$ (containing the pheromone gland) and $5^{\text {th }}$ tergites. Analyses of the expressed sequence tags (ESTs) from these segments allowed us to compare their genetic profiles and expand the spectrum of molecules possibly associated with the terpenoid pheromone. In addition, this source can also serve as a basis for future molecular research on pheromone biosynthesis and contribute to the understanding of other aspects of this insect's biology.

\section{Methods}

Insects

A L. longipalpis (Diptera: Psychodidae) one-spot population was collected from Gruta da Lapinha, Municipality of Lagoa Santa Minas Gerais, Brazil (19 $\left.38 \mathrm{~S} ; 43^{\circ} 53 \mathrm{~W}\right)$. This population was colonized according to [50] at a temperature of $26^{\circ} \mathrm{C}, 80 \%$ relative humidity, and a $12: 12 \mathrm{LD}$ photoperiod. We used sand flies from the $1^{\text {st }}$ to $7^{\text {th }}$ generations after checking for their (S)-9-methylgermacrene-B production according to the procedures indicated in [17]. This population was maintained at the Laboratorio de Bioquímica e Fisiologia de Insetos at the Instituto Oswaldo Cruz, Rio de Janeiro, Brazil. A permit for sand fly collection was obtained from the Brazilian Ministry of Environment (SISBIO\#26066-1). Tissues were extracted from male sand flies fed on a $70 \%$ sucrose solution for up to 7 days post-emergence.

\section{Dissections and RNA preparations}

Three different tissues were carefully dissected, the $4^{\text {th }}$ abdominal segment (LL-phg) containing the pheromone gland, as well as the $3^{\text {rd }}$ (LL3-seg) and $5^{\text {th }}$ (LL5-seg) abdominal tergites (Figure 1). After removing the midgut, the dissected segments were thoroughly washed in sterilized $0.9 \%$ saline solution in order to minimize any risk of contamination. One hundred units of the $3^{\text {rd }}$ abdominal segment were pooled together and preserved in an RNA preservation solution (RNAlater/Ambion) to obtain $200 \mathrm{ng}$ of mRNA, the mRNA quantity used in [51]. The same procedure was repeated for each of the tissues analyzed. Messenger RNA from each tissue was purified

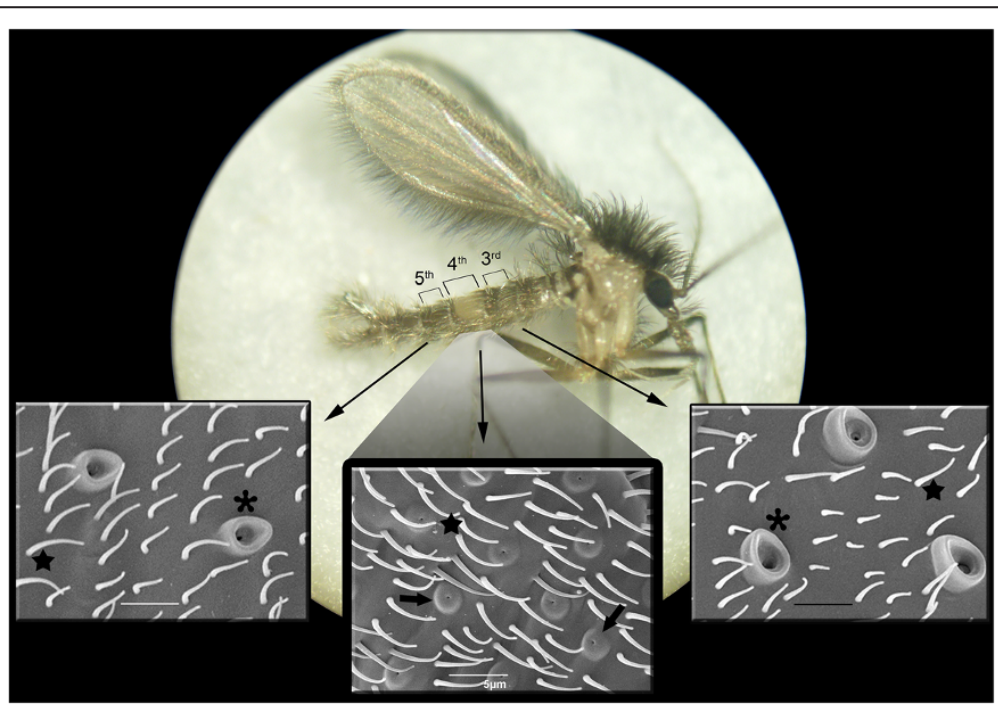

Figure 1 Tissues of $L$. longipalpis male included in this study. The stereoscope image of a $L$. longipalpis male illustrates the three abdominal segments $\left(3^{\text {rd }}, 4^{\text {th }}\right.$ and $\left.5^{\text {th }}\right)$ analyzed. Characteristics of these segments are shown by scanning electron microscopy. Pheromone disseminating structures, which are present in the $4^{\text {th }}$ abdominal segment are indicated by the arrowhead. Macrotrichias present in the $3^{\text {rd }}$ and $5^{\text {th }}$ segment are indicated by the asterisks, and microtrichias, which are present in all abdominal segments, are indicated by the star. 
with the Micro-FastTrack mRNA isolation kit (Invitrogen, San Diego, CA, USA) and kept at $-80^{\circ} \mathrm{C}$.

\section{Library construction and DNA sequencing}

Following [47,51,52], a full-length, enriched, directionally cloned cDNA library was generated for each abdominal segment using the SMART (Switching Mechanism At $5^{\prime}$ end of RNA Transcript) cDNA library construction kit (Clontech Laboratories, Montana View, CA). This technique uses oligoribonucleotide (SMART IV) to attach an identical sequence at the $5^{\prime}$ end of each reversetranscribed cDNA strand. This sequence is then utilized in subsequent PCR reactions and restriction digests.

First-strand cDNA was synthesized using PowerScript reverse transcriptase at $42^{\circ} \mathrm{C}$ for $1 \mathrm{~h}$ in the presence of SMART IV and CDS III ( $\left.3^{\prime}\right)$ primers. Second-strand synthesis was performed by a long-distance PCR-based protocol using Advantage Taq polymerase (Clontech) mix in the presence of the $5^{\prime} \mathrm{PCR}$ prime and the CDS III ( $\left.3^{\prime}\right)$ primer. These two primers create SfiI A and B restriction enzyme sites at the ends of the nascent cDNA. Double-strand cDNA synthesis was carried out on a Perkin Elmer 9700 Thermal cycler (Perkin Elmer Corp., Foster City, CA, USA) in the following conditions: $95^{\circ} \mathrm{C}$ for $1 \mathrm{~min}, 19$ cycles of $95^{\circ} \mathrm{C}$ for $10 \mathrm{~s}$, and $68^{\circ} \mathrm{C}$ for $6 \mathrm{~min}$. Double-stranded cDNA was immediately treated with proteinase $\mathrm{K}(0.8 \mu \mathrm{g} / \mathrm{ml})$ at $45^{\circ} \mathrm{C}$ for $20 \mathrm{~min}$, and the enzyme was removed by ultrafiltration though a Microcon YM-100 centrifugal filter device (Amicon Inc., Beverly, California, USA). The cleaned, double-stranded cDNA was then digested with $S f i I$ at $50^{\circ} \mathrm{C}$ for $2 \mathrm{~h}$, followed by size fractionation on a ChromaSpin-400 column (Clontech Laboratories, Mountain View,CA) into small $(\mathrm{S})$, medium $(\mathrm{M})$, and large $(\mathrm{L})$ transcripts. The profile of the fractions was checked on a 1.1\% agarose gel, and fractions containing cDNAs of more than $400 \mathrm{bp}$ were pooled and concentrated using a Microcon YM-100.

The cDNA was ligated into the $\lambda$ TripIEx2 vector (Clontech), and the resulting ligation reaction was packed using the Gigapack ${ }^{\circledR}$ Gold III Plus packaging extract (Stratagene, La Jolla, California, USA) according to the manufacturer's instructions. The package library was plated by infecting log-phase XL1-Blue Escherichia coli cells (Contech). The percentage of recombinant clones was determined by blue-white selection screening on LB plates containing X-gal/IPTG. Recombinant plaques were selected and picked using a sterilized wooden stick and placed into $75 \mu \mathrm{L}$ of ultrapure water in a 96-well vbottom plate. The plates were covered and placed on a gyrating shaker for $30 \mathrm{~min}$ at room temperature. The phage suspension was either immediately used for PCR or stored at $4^{\circ} \mathrm{C}$ for future use. The inserts were amplified using specific library vector primers, PT2F1 (5'-AAGTACTCTAGCAATTGTGAGC-3') and PT2R1
(5'-CTCTTCGCTACGCCAGCTG-3'), flanking the inserted cDNA. The PCR conditions were: 1 cycle of $75^{\circ} \mathrm{C}$ for $3 \mathrm{~min}$; 1 cycle of $94^{\circ} \mathrm{C}$ for $3 \mathrm{~min} ; 33$ cycles of $94^{\circ} \mathrm{C}$ for $1 \mathrm{~min}, 49^{\circ} \mathrm{C}$ for $1 \mathrm{~min}, 72^{\circ} \mathrm{C}$ for $2 \mathrm{~min}$, and $72^{\circ} \mathrm{C}$ for $7 \mathrm{~min}$. We analyzed the quality of the PCR products by running $5 \mu \mathrm{L}$ of the sample on 1.1\% agarose gel and revealing them with SYBR Green.

In order to clean off salts, dNTPs, and primers, the PCR products were washed with ultrapure water three times using ExcelaPure 96-well UF PCR purification plates (Edge Biosystems, Gaithersburg, MD). Approximately 200-250 ng of each PCR product was then transferred to Thermo-Fast 96-well PCR plates (ABgene Corp, Epson, Surrey, UK) and shipped for sequencing to the Rocky Mountain Laboratories Genomics Unit as described in [52] along with the PT2F3 (5'-TCTCGGGA AGCGCGCCATTGT-3') primer. Sequencing reactions were prepared according to the manufacturer's protocol (BigDye ${ }^{\circledR}$ Terminator, Applied Biosystems, Inc.) by adding $1 \mu \mathrm{L}$ ABI BigDye ${ }^{\circledR}$ Terminator ready reaction mix v3.1 $(\mathrm{P} / \mathrm{N}$ 4336921), $1.5 \mu \mathrm{L}$ 5x ABI sequencing buffer $(\mathrm{P} / \mathrm{N}$ 4336699), and $3.5 \mu \mathrm{L}$ of water for a final volume of $10 \mu \mathrm{L}$. Cycle sequencing was performed at $96^{\circ} \mathrm{C}$ for $10 \mathrm{sec}, 50^{\circ} \mathrm{C}$ for $5 \mathrm{sec}, 60^{\circ} \mathrm{C}$ for $4 \mathrm{~min}$ for 27 cycles on either a Bio-Rad Tetrad 2 (Bio-Rad Laboratories, Hercules, CA) or ABI 9700 thermal cycler (Applied Biosystems, Inc.). Fluorescently labeled extension products were purified following Applied Biosystems' BigDye ${ }^{\circledR}$ XTerminator ${ }^{\mathrm{TM}}$ purification protocol and subsequently processed on an $\mathrm{ABI} 3730 \mathrm{xL}$ DNA Analyzer (Applied Biosystems, Inc.). Fluorescently labeled extension products were purified following the Applied Biosystems BigDye ${ }^{\circledR}$ XTerminator ${ }^{\mathrm{TM}}$ purification protocol and subsequently processed on an ABI 3730xL DNA Analyzer (Applied Biosystems, Inc.).

\section{Bioinformatics analyses}

Primers or vector sequences were removed from the expressed sequence tags (EST) and then assembled into contigs using a CAP assembly program [53]. As previously described, BLAST packages and ClustalW software were used to compare and align sequences, respectively [54]. The BLASTtx algorithms were performed for functional annotation of each transcript searching against the NCBInr protein and Gene Ontology databases [55]. Conserved protein domains were predicted using reverse position specific BLAST (rpsBLAST), which searches for matches in the conserved domain database CDD [56] as well as the Pfam [57], SMART [58], and KOG [59] databases. Subsets of several organism proteomes available in the NCBI, ENSEMBL, or VectorBase were also searched. Phylogenetic analysis and statistical neighbor-joining bootstrap tests were performed using MEGA package [60]. The presence of a signal peptide was investigated using the SignalP server. Beginning with methionine found in the first 300 predicted amino acids, expressed 
Table 1 Summary of the sequence results from $L$. longipalpis pheromone gland and adjacent tissues

\begin{tabular}{ll}
\hline \multicolumn{1}{c}{ All sequences } & \\
\hline Total sequence analyzed & 3547 \\
\hline High quality sequences & 2502 \\
\hline Contigs (clusters + singletons) & 1387 \\
\hline Singletons & 1273 \\
\hline Number of sequences assembled & 1229 \\
\hline Contigs with blast match score of Eval $<10-5$ & 751 \\
\hline Contigs with blast match score of Eval $>10-5$ & 636 \\
\hline
\end{tabular}

sequence tag (EST) segments were examined every threeframe translations. Protein O-glycosylation sites were predicted using the NetOGlyc 26 software. Statistical significance in the number of transcripts per contigs, between tissues, was analyzed using a Chi-square test.

\section{Results and discussion}

\section{Sequences overview}

In total 3,547 phage plaques were randomly selected and sequenced, of which approximately 1,200 came from each of the three abdominal segments and were sequenced separately. After Sanger sequencing, a total of 2,502 high quality sequences were obtained. From these sequences, 1,387 clusters or contiguous sequences were assembled, of which 1,273 were represented by a single EST or singleton (Table 1). We use the term "cluster" or "contig" to refer to consensus sequences and singletons from this point on. A putative function was assigned to each contig based on the sequence homology to the databases mentioned in the methods section.

Sequences of most of the contigs (751) had a significant BLAST match (E-val < 10E-5) according to all reference databases, whereas 636 contigs, mostly singletons, presented low or no homology to the consulted databases. A large portion of the low homology transcripts may represent untranslated regions of genes or novel $L$. longipalpis-specific gene products.

Each contig was assigned a possible function and grouped into functional categories according to the sequence homology to molecules identified by the BLAST results (E-value of less than 10E-5) from the NCBI nonredundant protein, the Gene Ontology and the conserved

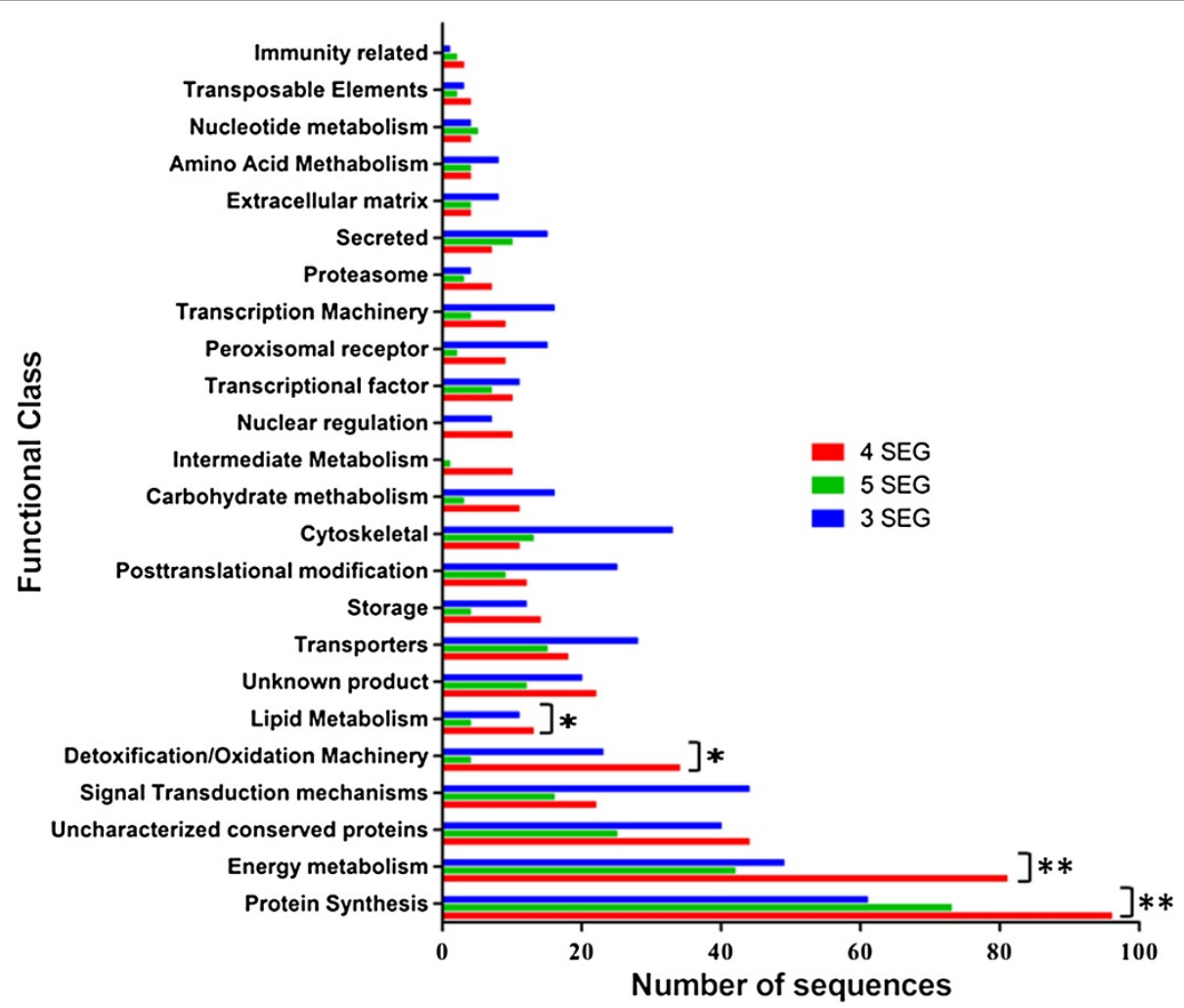

Figure 2 Distribution of the number of ESTs with homology to previously described proteins grouped into functional classes from the three tissues: LL4SEG ( $4^{\text {th }}$ segment containing the pheromone gland), LL3SEG ( $3^{\text {rd }}$ abdominal segment) and LL5SEG $\left(5^{\text {th }}\right.$ abdominal segment). Functional classification of the transcripts was based on their sequence similarity to the proteins in the reference databases. A Chi-square test was performed for each EST tissue group across the functional categories to examine the differences between tissues. The double-asterisks represents functional classes where both differences in the number of ESTs were statistically significant $\left(4^{\text {th }}\right.$ and $3^{\text {rd }} ; 4^{\text {th }}$ and $\left.5^{\text {th }}\right)$ and the single asterisk represents functional classes where only one difference in the number of ESTs was statistically significant. 
domain databases. Figure 2 shows the sequence abundance compared by tissue of origin across each functional category. This comparison was made after summing the contig sequences within each functional category for each tissue.

Although this histogram only shows the molecules identified by the sequence homology, it may approximately describe the biochemical characteristics of each tissue. We found more ESTs on the $4^{\text {th }}$ abdominal segment than the $3^{\text {rd }}$ and $5^{\text {th }}$ segments in some functional categories. For example, in the protein synthesis functional class we observed an increase of $35 \%$ in the number of ESTs on the $4^{\text {th }}$ segment relative to the $3^{\text {rd }}$, and an increase of $31 \%$ on the same segment relative to the $5^{\text {th }}$. These differences were statistically significant $\left(4^{\text {th }}\right.$ and $3^{\text {rd }}$ segments, $x^{2}==7.8, p$-value $=5 . E-03 ; 4^{\text {th }}$ and $5^{\text {th }}$ segments, $x^{2}=3.13, p$-value $=8$.E-02). Similarly, in the energy metabolism functional class the greater number of ESTs found on the $4^{\text {th }}$ abdominal segment relative to the $3^{\text {rd }}$ and $5^{\text {th }}$ segments were also statistically significant $\left(4^{\text {th }}\right.$ seg and $3^{\text {rd }}$ seg $x^{2}=7.88$ and $p=5 E-03$; $4^{\text {th }}$ seg and $5^{\text {th }}$ seg $X^{2}=12.37$ and $\left.\mathrm{p}=4 \mathrm{E}-04\right)$. This is interesting considering greater production of proteins in the $4^{\text {th }}$ abdominal segment may be related to the pheromone biosynthetic machinery and the consequent energy cost. We also observed the same pattern of a greater number of ESTs on the $4^{\text {th }}$ abdominal segment for the lipid metabolism functional class, though the difference was statistically significant between the $4^{\text {th }}$ and $5^{\text {th }}$ segments only $\left(4^{\text {th }}\right.$ seg and $3^{\text {rd }}$ seg, $X^{2}=0,17, p=6,8 \mathrm{E}-01 ; 4^{\text {th }}$ seg and $5^{\text {th }}$ seg, $X^{2}=20,83 p=5$.E-06). Similarly, we also observed more ESTs of the detoxification/oxidation functional class on the $4^{\text {th }}$ abdominal segment than the $3^{\text {rd }}$ or $5^{\text {th }}$ segments where the difference was statistically significant with the $5^{\text {th }}$ segment only $\left(4^{\text {th }}\right.$ seg and $3^{\text {rd }}$ seg, $X^{2}=$ $2,12, p=1 \mathrm{E}-01 ; 4^{\text {th }}$ seg and $5^{\text {th }}$ seg, $\chi^{2}=23,68 p=1$.E-06). Figure 2 highlights these functional classes and differences. These are not surprising findings considering the lipid metabolism and detoxification/oxidation machinery functional classes may include genes potentially associated to pheromone biosynthesis. The assembled contigs and BLAST results described in this paper are available in the hyperlinked Additional file 1.

Transcripts possibly representing enzymes of the classical isoprenoid pathway

In looking further into the group of sequences of the lipid metabolism and detoxification/oxidation functional class, we identified molecules grouped into 10 contigs potentially representing four of the seven enzymes of the mevalonate pathway. Additionally, we also found sequences similar to farnesyl diphosphate synthase (intermediate metabolism functional class) and NADP +

Table 2 Putative L. longipalpis pheromone gland-associated proteins; best matched results with corresponding E values from BLAST inquiries of a GenBank derived non-redundant protein database (NR) and Swiss protein database

\begin{tabular}{|c|c|c|c|c|c|c|c|}
\hline \multirow{2}{*}{$\begin{array}{l}\text { Assembled } \\
\text { contig }\end{array}$} & \multicolumn{3}{|c|}{$\mathrm{N}^{\circ}$ and origin of sequences } & \multirow{2}{*}{ Best match } & \multirow{2}{*}{ Database } & \multirow{2}{*}{ E-val } & \multirow{2}{*}{$\begin{array}{l}\text { Species of best } \\
\text { match }\end{array}$} \\
\hline & LL-4seg & LL-5seg & LL-3seg & & & & \\
\hline LLphg-contig_400 & 1 & 0 & 0 & HMG-R (gi|157122019) & NR & 4.00E-33 & Aedes aegypti \\
\hline LLphg-contig_215 & 1 & 0 & 0 & HMG-R (gi|170035703) & NR & 3.00E-89 & Culex quinquefasciatus \\
\hline LLphg-contig_437 & 1 & 0 & 0 & PMK (gi|146424700) & NR & $2.00 \mathrm{E}-54$ & Bombyx mori \\
\hline LLphg-contig_397 & 1 & 0 & 0 & DMD (gi|91078238) & NR & 6.00E-03 & Tribolium castaneum \\
\hline LLphg-contig_53 & 3 & 0 & 0 & IDI (gi|157112433) & NR & 2.00E-68 & Aedes aegypti \\
\hline LLphg-contig_54 & 3 & 0 & 0 & IDI (gi|157112433) & NR & $2.00 \mathrm{E}-68$ & Aedes aegypti \\
\hline LLphg-contig_55 & 2 & 0 & 0 & IDI (gi|157112433) & NR & 4.00E-69 & Aedes aegypti \\
\hline LLphg-contig_56 & 1 & 0 & 0 & IDI (sp|O35760||DI1_RAT) & SWIISS prot. & $2.00 \mathrm{E}-16$ & Rattus norvegicus \\
\hline LLphg-contig_117 & 3 & 0 & 0 & IDI (gi|157112433) & NR-LIGHT prot. & 7.00E-70 & Aedes aegypti \\
\hline LLphg-contig_118 & 1 & 0 & 0 & IDI (gi|157112433) & NR-LIGHT prot. & $3.00 \mathrm{E}-65$ & Aedes aegypti \\
\hline LLphg-contig_93 & 3 & 0 & 0 & 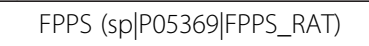 & SWIISS prot. & $6.00 \mathrm{E}-35$ & Rattus norvegicus \\
\hline LLphg-contig_94 & 2 & 0 & 0 & FPPS (sp|Q920E5|FPPS_MOUSE) & SWIISS prot. & $3.00 E-23$ & Mus musculus \\
\hline LLphg-contig_257 & 1 & 0 & 0 & FPPS (gi|17137582) & NR & 2.00E-34 & synthetic construct \\
\hline LLphg-contig_314 & 1 & 0 & 0 & FDH (gi|282934969) & NR & 2.00E-70 & Aedes aegypti \\
\hline LLphg-contig_333 & 1 & 0 & 0 & FDH (gi|282934969) & NR & $3.00 E-72$ & Tribolium castaneum \\
\hline
\end{tabular}

HMG-R: 3-hydroxy-3-methylglutaryl-coenzyme A reductase.

PMK: Phosphomevalonate kinase.

DMD: Diphosphomevalonate decarboxylase.

IDI: Isopentenyl-diphosphate delta isomerase.

FPPS: Farnesyl diphosphate synthase.

FDH: NADP + -dependent farnesol dehydrogenase 2. 
dependent farnesol dehydrogenase of the isoprenoid pathway (Table 2). All these potentially isoprenoidpathway related sequences were found on the $4^{\text {th }}$ abdominal segment only. These were not such surprising findings considering, as observed in other insects, the site where terpenoid production occurs activates the mevalonate pathway genes $[44,61,62]$. Figure 3 shows the classical isoprenoid biosynthetic pathway adapted from the 00900 interactive map of the Kyoto Encyclopedia of genes and genomes KEGG [63]. Enzymes for which transcripts have been identified are highlighted in the red boxes of the same figure.

\section{3-hydroxy-3-methyl-glutaryl-CoA reductase - HMG-R (EC} 1.1.1.34)

We identified sequences grouped in two clusters (contigs 215 and 400) potentially encoding 3-hydroxy-3-methylglutarylCoA reductase (HMG-R). This enzyme has two known forms, Class I and Class II, which are present in eukaryotes and prokaryotes catalyzing the synthesis of mevalonate [64]. Although the sequences found in our library seem to be incomplete, they presented high homology to the HMG-Rs described in other insects such as Culex quinquefasciatus and Aedes aegypti (See Additional file 1 for BLAST results). They putatively encode part of the C-terminal portion of

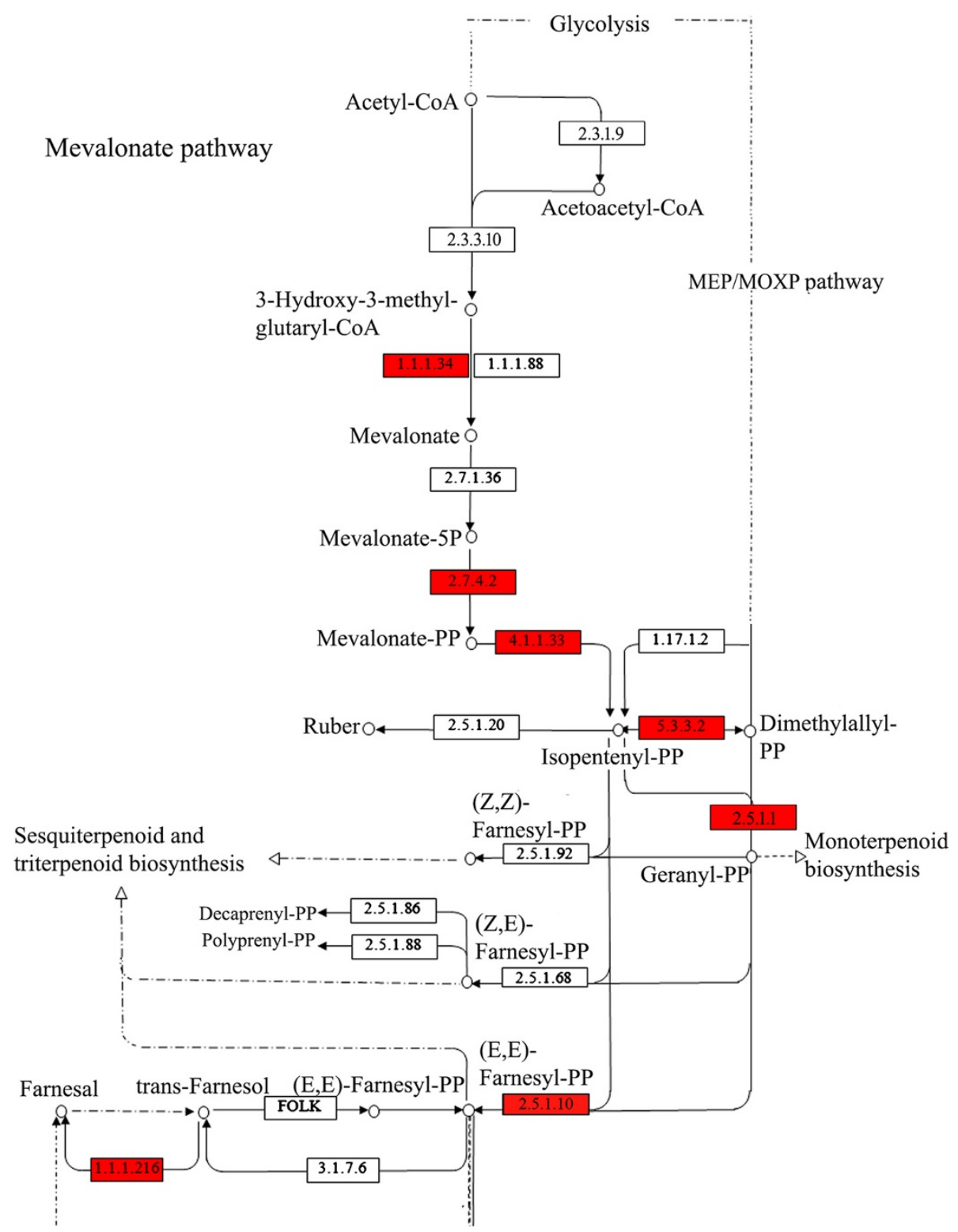

Figure 3 Scheme of the classical isoprenoid pathway exhibiting enzymes for which transcripts have been identified. Enzymes for which transcripts have been identified in the L. longipalpis pheromone gland only are highlighted in red. 


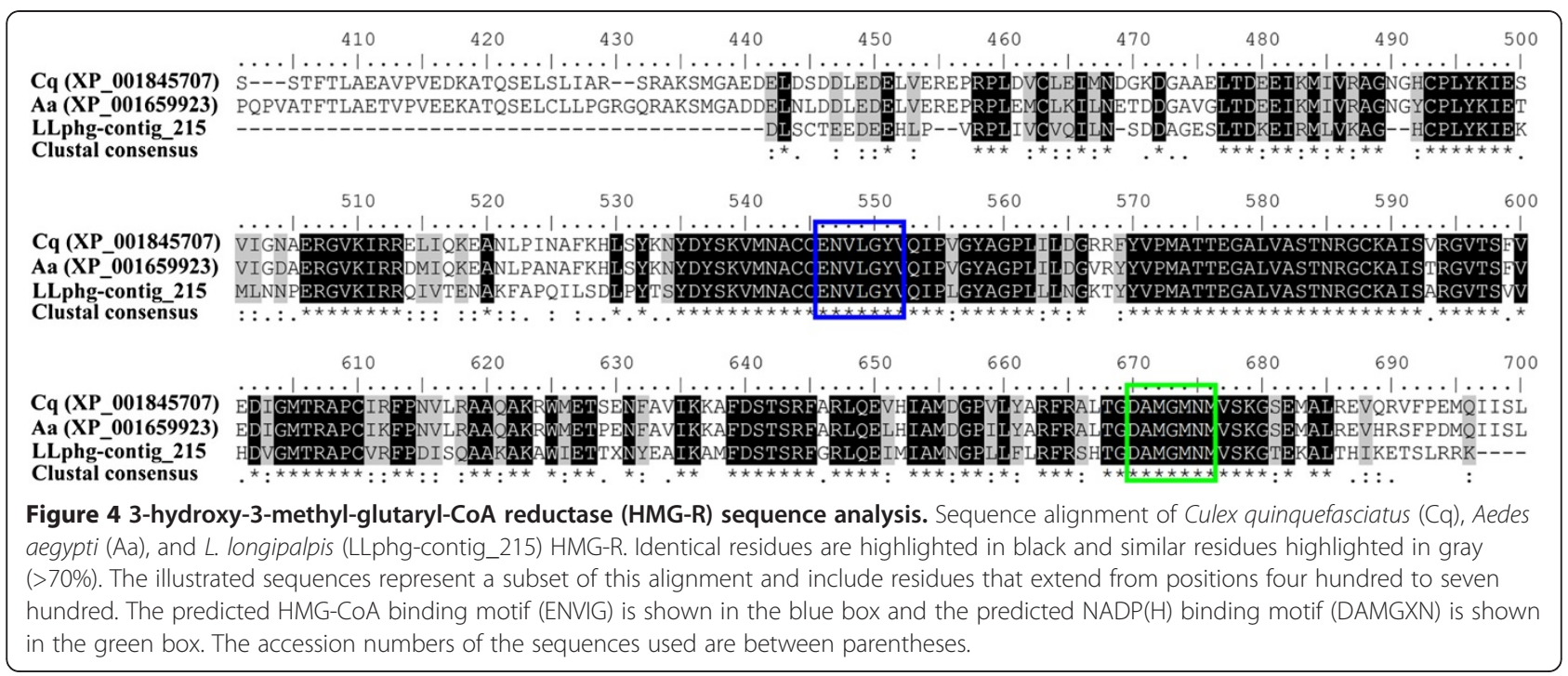

the enzyme, which is a highly conserved region containing the catalytic domain [65]. The alignment of the HMG-R Cterminal sequence of the longest transcript (contig 215) and the homologous sequences of other insects is shown in Figure 4. The conserved motifs common to HMG-R class I and II [64] are also displayed in the same figure. These motifs include the ENVIG sequence, which has a role in the
HMG-CoA binding, and the DAMGXN motif, which has a role in the $\operatorname{NADP}(\mathrm{H})$ binding. The LLphg-contig _ 400 sequence was not used in this analysis due to its incompleteness. The differentiated expression for the gene encoding HMG-R and its links to terpenoid pheromone production have been reported in various coleopteran species such as Anthonomus grandis [66],

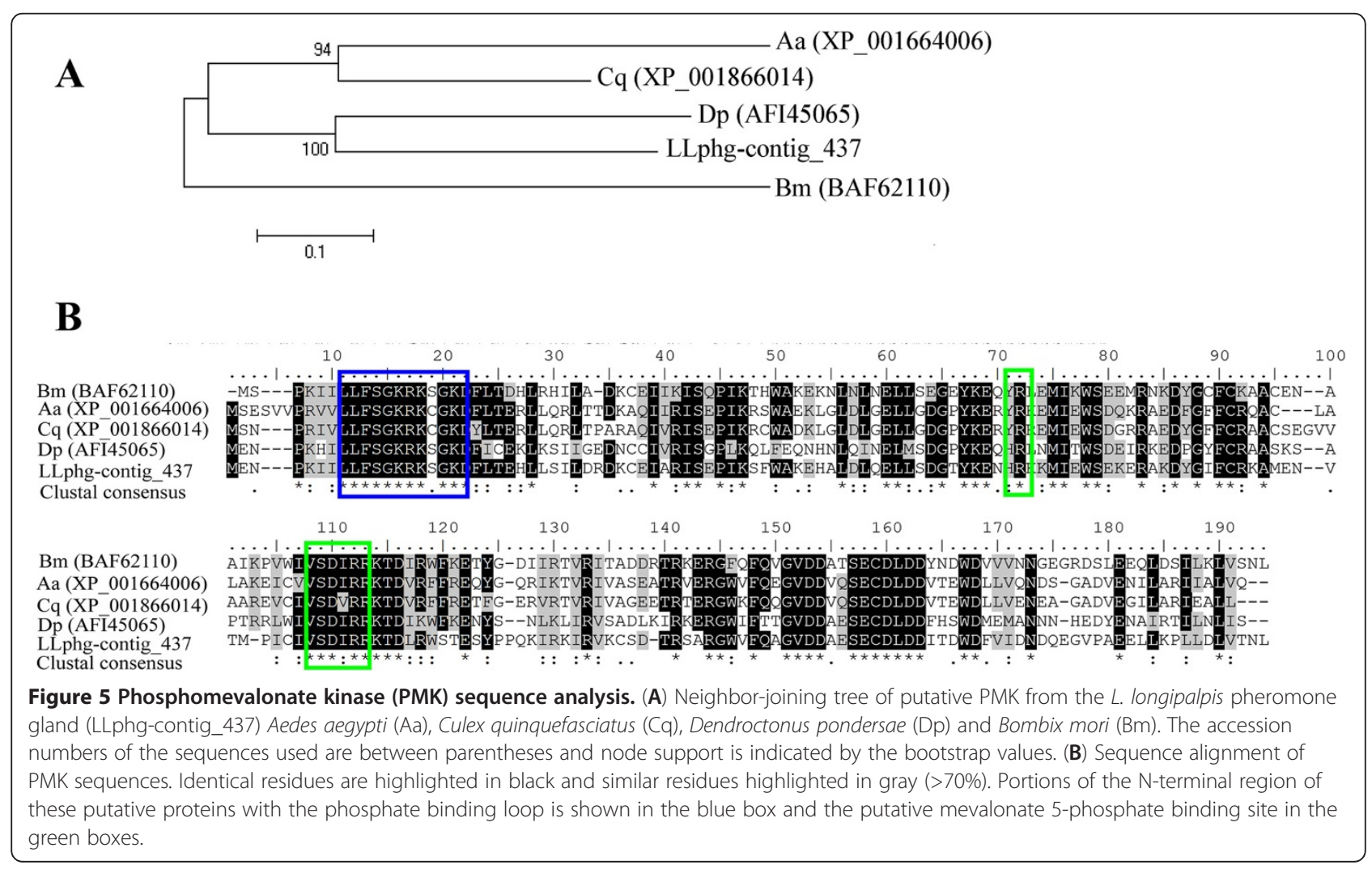


Ips paraconfusus [67], Ips pini [68] and Dendroctonus jeffreyi $[69,70]$.

\section{Phosphomevalonate kinase - PMK (EC 2.7.4.2)}

A unique phosphomevalonate kinase transcript (contig 437) was identified with a predicted peptide sequence of 187 amino acids. The role of this enzyme is to catalyze the reversible reaction of mevalonate-5-phosphate and ATP to produce mevalonate-5-diphosphate as well as ADP. Sequence searches against the consulted databases presented the highest similarity score to the PMK of Aedes aegypti (XP_001664006), Culex quinquefasciatus (XP_001866014) and to the PMK found in Bombix mori (BAF62110). Figure 5A also exhibits the comparison of our sequences to the PMK sequence found in the specialized tissues for pheromone production of Dendroctonus pondesorase [61]. Protein domains directly involved in mevalonate 5-phosphate phosphorylation [71,72] and ATP binding [73] were recognized in the predicted amino acid sequence of PMK (Figure 5B).

Diphosphomevalonate decarboxylase - DMD (EC 4.1.1.33) From contig 397 we identified a short cDNA fragment having the putative domain of diphosphomevalonate decarboxylase according to the KOG database. Despite its incompleteness, we have included this sequence in our analysis considering it may be used in future studies. This enzyme, also known as mevalonate diphosphate decarboxylase (MDD) or mevalonate pyrophosphate decarboxylase (MPD) performs the crucial step in isoprenoids biosynthesis [74] catalyzing the ATP dependent decarboxylation of the mevalonate 5-diphosphate (MDP) to yield isopentenyl diphosphate (IPP) [75]. The transcript for this enzyme was also described in the midgut of male Ips pini, where monoterpenoid pheromone production occurs [76].

Isopentenyl diphosphate delta isomerase - IDI (EC 5.3.3.2) This enzyme catalyzes an essential activation in the isoprenoid biosynthetic pathway by converting isopentenyl diphosphate isomerase (IPP) to its electrophilic allylic isomer dimethylallyl diphosphate (DMAPP). IPP and DMAPP are the assembly blocks of isoprenoid compounds. We identified thirteen sequences grouped into six contigs possibly representing IDI. Contrary to the singletons (contig 56 and 118), the remaining contigs were assembled using more than one sequence. Contigs number 53, 54, and 117 were assembled with three sequences each, while contig 55 resulted from two sequences. The longest transcripts accessed from our library were compared to isopentenyl diphosphate delta isomerase found in the genome of Aedes aegypti (XP_001657533), Culex quinquefasciatus (XP_001868438) and expressed in

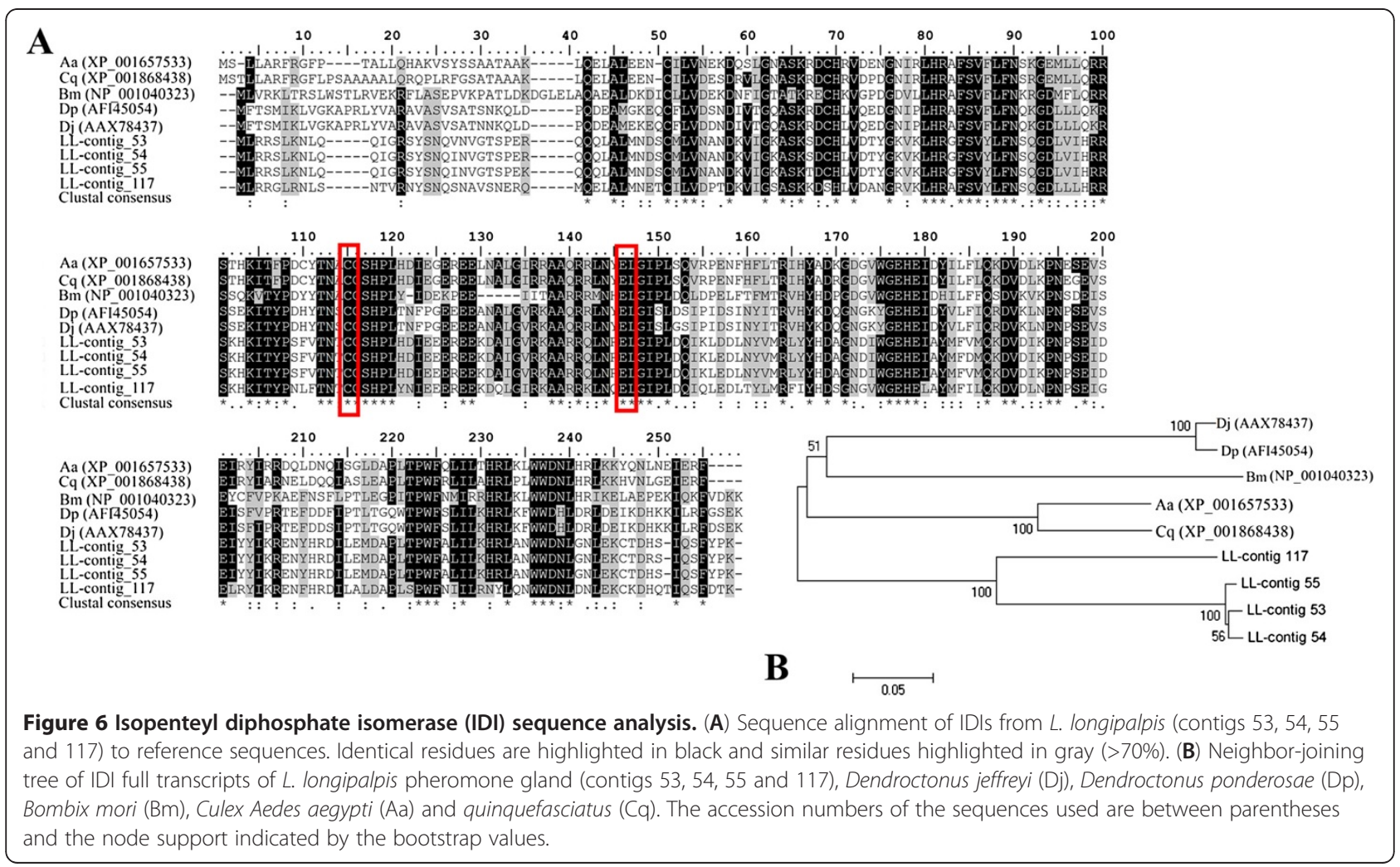


the corpora allata of Bombix mori (NP_001040323.2). We also compared our transcripts to IDI sequences identified in coleopteran insects such as Dendroctonus jeffreyi (AAX78437) and Dendroctunus ponderosae (AFI45054) (Figure 6). Our phylogenetic analysis separated the $L$. longipalpis IDI-like sequences into two groups (Figure 6B), which may indicate that two forms of IDI are probably occurring in this species. The catalytic residues (reviewed in [77]) are shown in Figure 6A. The same figure exhibits the high level of similarity and identity among the sequences.

Farnesyl diphosphate synthase - FPPS (EC 2.5.1.1./2.5.1.10) In the group of sequences classified as part of the intermediate metabolism functional class we identify molecules from three contigs (93, 94 and 257) potentially encoding farnesyl diphosphate synthase, FPPS. Enzymes catalyzing the consecutive condensation of IPP with DMAPP are known as prenyltransferases or isoprenyl diphosphate synthase [33]. Geranyl diphosphate synthase (GPPS), farnesyl diphosphate synthase (FPPS), and geranylgeranyl diphosphate synthase (GGPPS) are classified as short chain prenyltransferases and are named according to their final product: geranyl pyrophosphate (GPP) and farnesyl pyrophosphate (FPP) (reviewed in [78]). In this study we identified FPPS and no GPPS, which may indicate that FPPS is possibly involved in the synthesis of both GPP and FPP. This dual enzyme activity has been proposed and supported in independent studies [40,79-81]. Since the first characterization of FPPS in the moth Agrotis ipsilin [82], searches for this enzyme have been conducted in other species $[35,83,84]$ and extended to other orders such as Coleoptera [79], Hemiptera $[40,81,85]$, as well as Diptera [36]. Although FPPS characterizations have been traditionally associated to juvenile hormone $(\mathrm{JH})$ biosynthesis (reviewed in [30]), representations of this enzyme have also been related to terpenoid-pheromone production in some insects $[40,79,86]$. A comparison of the L. longipalpis FPPS from contigs 93 and 94 to homologous sequences from other insects is shown in Figure 7.

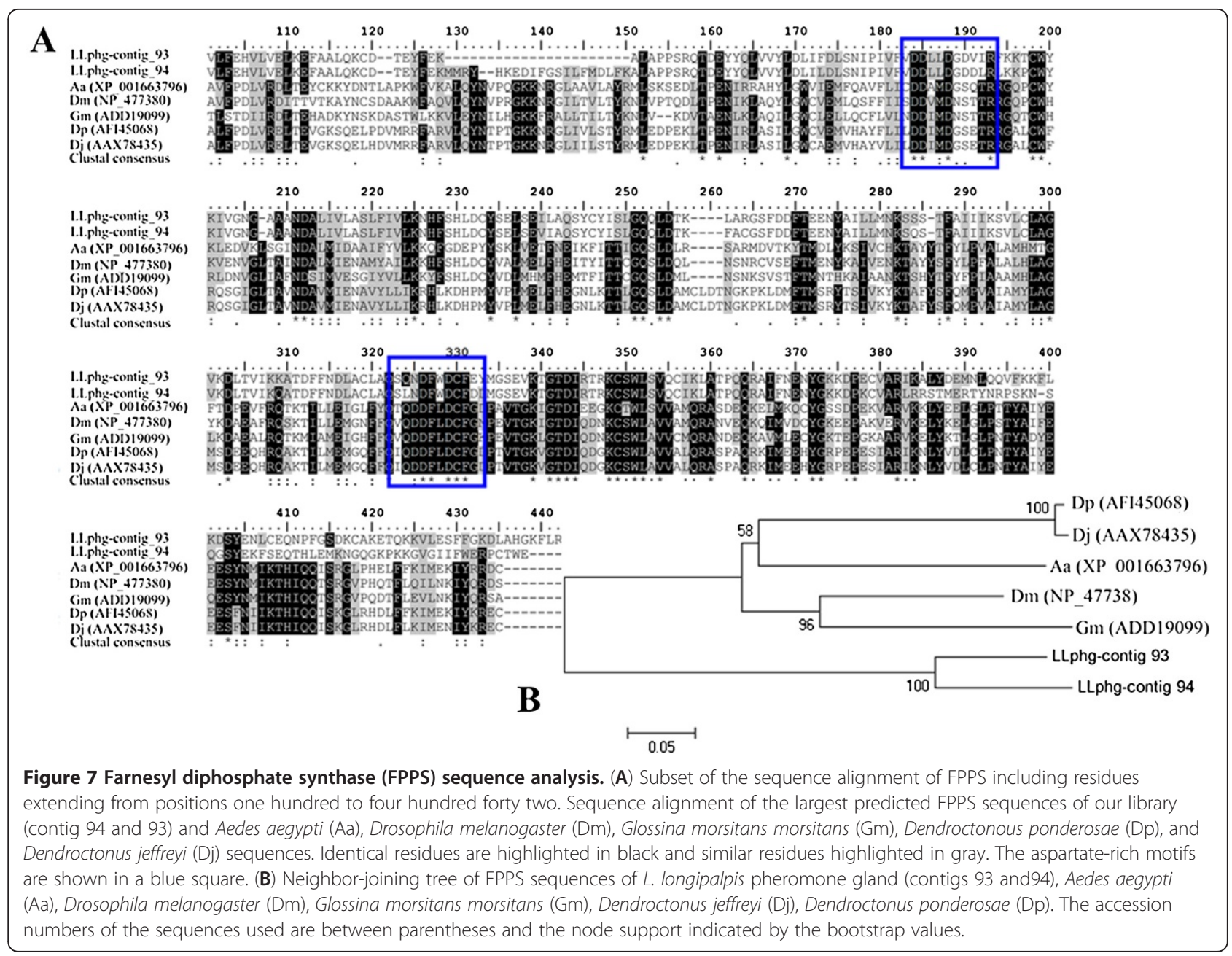




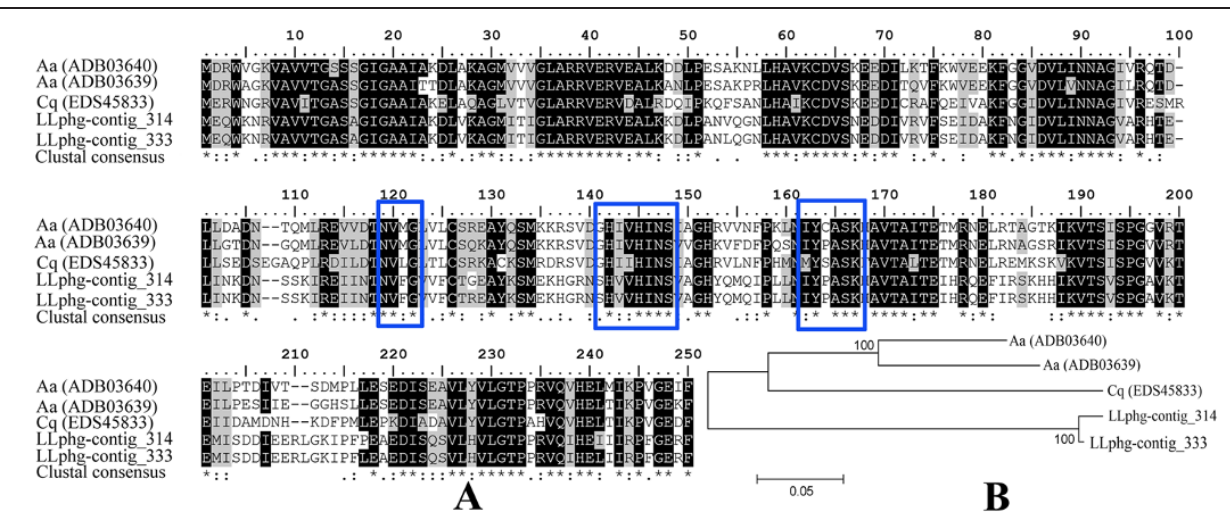

Figure 8 Farnesol dehydrogenase FDH sequence analysis. (A) Neighbor-joining tree and (B) sequence alignment of two Lutzomyia longipalpis farnesol dehydrogenases sequences and previously described enzymes from Culex quinquefasciatus (Cq) and Aedes aegypti (Aa). Identical residues are highlighted in black and similar residues in gray.

This figure also exhibits the characteristic aspartaterich motifs, which play an essential role in substrate binding and catalysis $[87,88]$.

\section{Farnesol dehydrogenase - FDH}

From contigs 314 and 333 we accessed two full-length cDNAs having $771 \mathrm{bp}$ ORFs encoding predicted peptides of 247-amino acids each. The predicted protein sequences were associated to the short chain dehydrogenase/ reductase (SDR) family as indicated by the SwissProt match. Additionally, by searching the NR database of the NCBI, our sequences presented a high degree of similarity to the NADP +-dependent farnesol dehydrogenase 2 (71-72\%) and NADP + -dependent farnesol dehydrogenase 1 (69-70\%) of Aedes aegypti (see Additional file 1 for blast results). This type of oxidoreductase has been previously characterized as being responsible for farnesol oxidation [89]. Figure 8 compares putative L. longipalpis FDH

Table 3 Putative L. longipalpis proteins; best matched results and corresponding E values from BLAST inquiries of a PFAM database

\begin{tabular}{|c|c|c|c|c|c|c|c|}
\hline \multirow{2}{*}{$\begin{array}{l}\text { Assembled } \\
\text { contig }\end{array}$} & \multicolumn{3}{|c|}{$\mathrm{N}^{\circ}$ and origin of sequences } & \multirow{2}{*}{$\begin{array}{l}\text { Functional } \\
\text { classification }\end{array}$} & \multirow{2}{*}{ Database } & \multirow{2}{*}{ Best match } & \multirow{2}{*}{ E-val } \\
\hline & LL-4seg & LL-5seg & LL-3seg & & & & \\
\hline LLphg-contig_82 & 1 & 4 & 0 & Secreted & PFAM & Haemolymph juvenile hormone binding protein & 7E-049 \\
\hline LLphg-contig_83 & 1 & 0 & 0 & Secreted & PFAM & Haemolymph juvenile hormone binding protein & 7E-050 \\
\hline LLphg-contig_141 & 0 & 0 & 2 & Secreted & PFAM & Haemolymph juvenile hormone binding protein & $3 \mathrm{E}-051$ \\
\hline LLphg-contig_142 & 0 & 0 & 1 & Secreted & PFAM & Haemolymph juvenile hormone binding protein & $9 \mathrm{E}-047$ \\
\hline LLphg-contig_143 & 0 & 0 & 1 & Secreted & PFAM & Haemolymph juvenile hormone binding protein & 9E-052 \\
\hline LLphg-contig_182 & 0 & 0 & 2 & Secreted & PFAM & Haemolymph juvenile hormone binding protein & $3 \mathrm{E}-059$ \\
\hline LLphg-contig_183 & 0 & 0 & 1 & Secreted & PFAM & Haemolymph juvenile hormone binding protein & $2 \mathrm{E}-030$ \\
\hline LLphg-contig_230 & 1 & 0 & 0 & Secreted & PFAM & Haemolymph juvenile hormone binding protein & $1 \mathrm{E}-024$ \\
\hline LLphg-contig_336 & 1 & 0 & 0 & Secreted & PFAM & Haemolymph juvenile hormone binding protein & $3 \mathrm{E}-020$ \\
\hline LLphg-contig_736 & 0 & 0 & 1 & Secreted & PFAM & Haemolymph juvenile hormone binding protein & $5 \mathrm{E}-025$ \\
\hline LLphg-contig_95 & 0 & 0 & 2 & Secreted & PFAM & OS-D/Insect pheromone-binding family & $1 \mathrm{E}-051$ \\
\hline LLphg-contig_96 & 1 & 0 & 0 & Secreted & PFAM & OS-D/Insect pheromone-binding family & $4 \mathrm{E}-042$ \\
\hline LLphg-contig_97 & 0 & 0 & 1 & Secreted & PFAM & OS-D/Insect pheromone-binding family & $1 \mathrm{E}-051$ \\
\hline LLphg-contig_98 & 0 & 1 & 0 & Secreted & PFAM & OS-D/Insect pheromone-binding family & $2 \mathrm{E}-006$ \\
\hline LLphg-contig_954 & 0 & 0 & 1 & Secreted & PFAM & General odorant binding protein family & $3 \mathrm{E}-027$ \\
\hline LLphg-contig_1236 & 0 & 1 & 0 & Secreted & PFAM & General odorant binding protein family & $1 \mathrm{E}-027$ \\
\hline LLphg-contig_78 & 2 & 0 & 0 & Secreted & PFAM & General odorant binding protein family & $3 \mathrm{E}-020$ \\
\hline LLphg-contig_79 & 2 & 0 & 0 & Secreted & PFAM & General odorant binding protein family & $2 \mathrm{E}-017$ \\
\hline LLphg-contig_80 & 1 & 0 & 0 & Secreted & PFAM & General odorant binding protein family & $6 \mathrm{E}-020$ \\
\hline LLphg-contig_81 & 1 & 0 & 0 & Secreted & PFAM & General odorant binding protein family & 9E-020 \\
\hline LLphg-contig_1059 & 0 & 0 & 1 & Secreted & PFAM & General odorant binding protein family & $3 \mathrm{E}-024$ \\
\hline
\end{tabular}


Table 4 Putative L. longipalpis proteins; best matched results and corresponding E values from BLAST inquiries of a GenBank derived non-redundant protein database (NR), KOG and Swiss prot databases

\begin{tabular}{|c|c|c|c|c|c|c|c|}
\hline \multirow{2}{*}{$\begin{array}{l}\text { Assembled } \\
\text { contig }\end{array}$} & \multicolumn{3}{|c|}{$\mathrm{N}^{\circ}$ and origin of sequences } & \multirow{2}{*}{ Class } & \multirow{2}{*}{ Database } & \multirow{2}{*}{ Best match } & \multirow{2}{*}{ E-val } \\
\hline & LL-4seg & LL-5seg & $\overline{\text { LL-3seg }}$ & & & & \\
\hline LLphg-contig_39 & 4 & 0 & 0 & Detox/ox & KOG & Cyt P450 CYP4/CYP19/CYP26 subfamilies & $1 \mathrm{E}-048$ \\
\hline LLphg-contig_40 & 0 & 2 & 2 & Detox/ox & KOG & Cyt P450 CYP4/CYP19/CYP26 subfamilies & 1E-063 \\
\hline LLphg-contig_41 & 0 & 0 & 3 & Detox/ox & KOG & Cyt P450 CYP4/CYP19/CYP26 subfamilies & $1 \mathrm{E}-106$ \\
\hline LLphg-contig_42 & 1 & 1 & 3 & Detox/ox & KOG & Cyt P450 CYP4/CYP19/CYP26 subfamilies & $1 \mathrm{E}-108$ \\
\hline LLphg-contig_43 & 0 & 0 & 1 & Detox/ox & KOG & Cyt P450 CYP4/CYP19/CYP26 subfamilies & $1 \mathrm{E}-044$ \\
\hline LLphg-contig_615 & 1 & 0 & 0 & Detox/ox & KOG & Cyt P450 CYP4/CYP19/CYP26 subfamilies & $6 \mathrm{E}-034$ \\
\hline LLphg-contig_792 & 0 & 0 & 1 & Detox/ox & KOG & Cyt P450 CYP4/CYP19/CYP26 subfamilies & $2 \mathrm{E}-052$ \\
\hline LLphg-contig_305 & 1 & 0 & 0 & Detox/ox & KOG & Cyt P450 CYP3/CYP5/CYP6/CYP9 subfamilies & $2 \mathrm{E}-072$ \\
\hline LLphg-contig_610 & 1 & 0 & 0 & Detox/ox & KOG & Cyt P450 CYP3/CYP5/CYP6/CYP9 subfamilies & $3 \mathrm{E}-071$ \\
\hline LLphg-contig_915 & 0 & 0 & 1 & Detox/ox & KOG & Cyt P450 CYP3/CYP5/CYP6/CYP9 subfamilies & $1 \mathrm{E}-111$ \\
\hline LLphg-contig_930 & 0 & 0 & 1 & Detox/ox & KOG & Cyt P450 CYP3/CYP5/CYP6/CYP9 subfamilies & $8 \mathrm{E}-083$ \\
\hline LLphg-contig_940 & 0 & 0 & 1 & Detox/ox & KOG & Cyt P450 CYP3/CYP5/CYP6/CYP9 subfamilies & $3 \mathrm{E}-087$ \\
\hline LLphg-contig_1067 & 0 & 0 & 1 & Detox/ox & KOG & Cyt P450 CYP3/CYP5/CYP6/CYP9 subfamilies & $2 \mathrm{E}-083$ \\
\hline LLphg-contig_156 & 1 & 0 & 0 & Detox/ox & NR & Glutathione S-transferase & $2 \mathrm{E}-066$ \\
\hline LLphg-contig_157 & 0 & 1 & 0 & Detox/ox & NR & Glutathione S-transferase & $3 \mathrm{E}-080$ \\
\hline LLphg-contig_158 & 1 & 0 & 0 & Detox/ox & NR & Glutathione S-transferase & $4 \mathrm{E}-081$ \\
\hline LLphg-contig_774 & 0 & 0 & 1 & Detox/ox & NR & Glutathione S-transferase & $1 \mathrm{E}-102$ \\
\hline LLphg-contig_789 & 0 & 0 & 1 & Detox/ox & NR & Glutathione S-transferase & $1 \mathrm{E}-124$ \\
\hline LLphg-contig_1066 & 0 & 0 & 1 & Detox/ox & NR & Glutathione S-transferase & $5 E-087$ \\
\hline LLphg-contig_367 & 1 & 0 & 0 & Detox/ox & SWISSP prot. & Juvenile hormone epoxide hydrolase 1 & $3 \mathrm{E}-094$ \\
\hline LLphg-contig_868 & 0 & 0 & 1 & Detox/ox & SWISSP prot. & Juvenile hormone epoxide hydrolase 2 & $2 \mathrm{E}-047$ \\
\hline
\end{tabular}

sequences with the previously described enzymes and also exhibits amino acid motifs of the enzymes' active site [90].

This is a first study describing transcripts potentially related to enzymes making up the mevalonate pathway and prenyltransferase in L. longipalpis. Considering we identified these transcripts from a specialized tissue where terpenoid pheromone production occurs, these genes may be the subject of future research addressing their relationship with pheromone production.

\section{Transcripts associated with secreted proteins}

From the sequences obtained from all three tissues containing peptide signals, an indication of secretion (Table 3), we identified molecules with predicted protein domains of odorant/pheromone binding proteins and juvenile hormone binding proteins (JHBP).

\subsection{Transcripts related to insect odorant binding protein (OBP)}

Members of this family are ubiquitous in insects and are specialized in carrying small hydrophobic ligands through aqueous media [91]. According to PFAM database searches, sequences grouped in seven contigs $(78,79,80,81,1059$, 954 and 1236) presented conserved domains of pheromone/ odor binding proteins. Additionally, sequences from contig 954 and 1236 presented similarity to the 99a OBP sequence described in C. quinquefasciatus (EDS45783) deposited in the NR database. Another group of sequences reunited in contigs 95, 96, and 98 also presented a high degree of similarity to proteins referred as OS-D proteins, chemosensory proteins (CSPs) or sensory appendage proteins (SAPs), based on their association with insect sensory organs [92]. Given these molecules are highly conserved across species [92], our finding led us to consider the possibility that they may also facilitate pheromone transportation between the pheromone gland and the external environment, as in moths [93-95].

\section{Juvenile hormone binding protein (JHBP)}

Ten molecules were identified as probable haemolymph juvenile hormone binding proteins (JHBP). It is known that JHBPs transport the highly hydrophobic insect juvenile hormone $(\mathrm{JH})$ from the most important site of its synthesis (the corpora allata) to target tissues [96,97]. By analogy to the role of $\mathrm{JHs}$ in the regulation of pheromone production in beetles, cockroaches, and moths [98-101] the possible expression of JHBP in the tissues analyzed here may represent trace evidence of a similar function in L. longipalpis. However, it is also possible that due to the chemical similarity between the JHs and the L. longipalpis sesquiterpene pheromone, the JHBP 
gene products might bind both $\mathrm{JH}$ and L. longipalpis pheromones.

\section{Transcripts related to detoxification/oxidation machinery Cytochrome P450}

Another interesting group of transcripts were those encoding putative cytochrome P450 enzymes. These sequences were grouped into thirteen contigs obtained from all three tissues used in this analysis (Table 4). Cytochrome P450 (CYP) comprises a large family of heme-thiolate enzymes that metabolize a wide range of endogenous and exogenous compounds. In insects, these enzymes are found in virtually all tissues [102] and catalyze the metabolism of exogenous substances and participate in the biosynthesis and degradation of juvenile hormones, ecdysteroids, and pheromones [103-105]. In our work, two $\mathrm{P} 450$ protein subfamilies were identified: CYP4/CYP19/CYP26 and CYP3/CYP5/CYP6/CYP9, according to the eukaryotic orthologous group database (KOG). The CYP4/CYP19/CYP26 subfamily was the most abundant and it was represented in contigs 39, $40,41,42,43,615$, and 792. The occurrence of a higher abundance of transcripts for CYP4 and CYP3 P450 protein families was also recently described in a transcriptome study of different Dendroctonus ponderosae tissues, including the terpenoid pheromone production site [61].

\section{Glutathione S-transferase}

Another noticeable gene involved in biotransformation is the glutatione S-transferase. We identified sequences grouped into six contigs $(156,157,158,774,789$, and 1066) with high similarity to glutation S-transfererase previously described in L. longipalpis (Table 4 and Additional file 1). Besides its important role for detoxification, especially in phytophagous insects [106], these molecules have also been described as odor degradation enzymes in some insects [107].

\section{Juvenile hormone epoxide hydrolase - JHEH}

After consulting the SWISSP database two transcripts presented high sequence similarity to juvenile hormone epoxide hydrolase $(\mathrm{JHEH})$, one obtained from the $4^{\text {th }}$ abdominal segment library containing the pheromone gland (contig 367), and the other from the $3^{\text {rd }}$ abdominal segment library (contig 868). The JHEHs together with the juvenile hormone esterase (JHE) are known as enzymes having a role in $\mathrm{JH}$ degradation [108].

\section{Conclusion}

This study has confidently generated a list of transcripts expressed in the pheromone gland and adjacent tissues. Molecules associated to enzymes of the mevalonate pathway were found only in the $4^{\text {th }}$ abdominal segment (containing the pheromone gland). The identification of these enzymes was facilitated by the conservation of the mevalonate pathway between insect species and vertebrates [30]. However, this conservation is not present in the later steps of isoprenoid compound production, which involves several paths leading to different final products. With the exception of juvenile hormones [30], there is little available information on the biosynthesis of cyclic sesquiterpene or homosesquiterpene compounds in insects. Such advances in this field could contribute to the identification of the specialized enzymatic machinery through a classical homology inference. In this context, the unmatched groups of sequences we obtained from the $4^{\text {th }}$ abdominal segment constitute a useful resource for future explorations of the specialized enzymatic components of (S)-9-methylgermacrene-B production.

Furthermore, in this work we also present a set of interesting genes potentially related to the insect OBP protein family, including molecules similar to chemosensory proteins. This finding also provides an interesting subject for future studies considering its potential implication for pheromone transportation [93] or other functions [109]. This transcriptome sequence resource may also provide new molecular tools for future studies of other terpeneproducing L. longipalpis populations. Finally, our results may also serve to identify potential targets for genetic manipulation techniques for population monitoring and control of L. longipalpis, considering this insect carries the parasite causing an important and neglected tropical disease, visceral leishmaniasis.

\section{Additional file}

Additional file 1: Excel File with assembled contigs and BLAST results.

\section{Competing interests}

The authors declare that they have no competing interests.

\section{Authors' contributions}

Conceived and designed the experiments: NGC, PC and RPB. Performed the experiments: NGC and JGV. Analyzed the data: NGC, JGV and JMR. Contributed reagents/materials/analysis tools: RPB, JGV and JMR. Wrote the paper: NGC, PC and RPB. All authors read and approved the final version of the manuscript.

\section{Acknowledgements}

This work was supported by the Coordenação de Aperfeiçoamento de Pessoal de Nivel Superior (CAPES), Fundação de Amparo à Pesquisa do Estado do Rio de Janeiro (FAPERJ) and the Division of Intramural Research, the National Institute of Allergy and Infectious Disease. The funders had no role in study design, data collection and analysis, decision to publish, or preparation of the manuscript.

We are thankful to the Research Technologies Section, Rocky Mountain Laboratories, National Institute of Allergy and Infectious Diseases, National Institutes of Health, Hamilton, MT 59840, USA, for DNA sequencing. We are also grateful to Dr. Jacenir Reis Santos-Mallet, Dr. Susana Corte-Real, and Rozana Corte-Real for their collaboration, and the multiuser platform for electron microscopy at the Instituto Oswaldo Cruz (FIOCRUZ) for the use of its scanning electron microscope. We would also like to acknowledge Francisco de Assis Marra for technical assistance, Mariel Figueroa, Caroline da Silva Moraes, and 
Andressa Fuzari Rodrigues for their valuable assistance in experimental work, and Nathalia Pinho de Souza for her help with the figures.

\section{Author details}

'Laboratório de Bioquímica e Fisiologia de Insetos, IOC, FIOCRUZ, Av. Brasil 4365, Manguinhos, Pav. Leônidas Deane, Sala 213, Rio de Janeiro, RJ CEP: 21040-360, Brasil. ${ }^{2}$ Laboratory of Malaria and Vector Research, NIAID, NIH, Rockville, MD, USA. ${ }^{3}$ Laboratório de Pesquisa em Leishmaniose, IOC, FIOCRUZ, Rio de Janeiro, RJ, Brasil.

Received: 6 December 2012 Accepted: 19 February 2013 Published: 7 March 2013

\section{References}

1. Deane LM, Deane MP: Visceral leishmaniasis in Brazil: geographical distribution and transmission. Rev Inst Med Trop Sao Paulo 1962, 4:149-212.

2. Lainson R, Rangel EF: Lutzomyia longipalpis and the eco-epidemiology of American visceral leishmaniasis, with particular reference to Brazil: a review. Mem Inst Oswaldo Cruz 2005, 100(8):811-827.

3. Palatnik-de-Sousa CB, Day MJ: One Health: the global challenge of epidemic and endemic leishmaniasis. Parasit Vectors 2011, 4(1):1-10.

4. Bray DP, Alves GB, Dorval ME, Brazil RP, Hamilton JG: Synthetic sex pheromone attracts the leishmaniasis vector Lutzomyia longipalpis to experimental chicken sheds treated with insecticide. Parasit Vectors 2010, 3:16.

5. Morton IE, Ward RD: Laboratory response of female Lutzomyia longipalpis sandflies to a host and male pheromone source over distance. Med Vet Entomol 1989, 3(3):219-223.

6. Quinnell R, Dye C: An experimental study of the peridomestic distribution of Lutzomyia longipalpis (Diptera: Psychodidae). Bull Entomol Res 1994, 84(3):379-382.

7. Lane R, Souza Bernardes D: Histology and ultrastructure of pheromone secreting glands in males of the phlebotomine sandfly Lutzomyia longipalpis. Ann Trop Med Parasitol 1990, 84(1):53-61.

8. Spiegel CN, Batista-Pereira LG, Bretas JAC, Eiras AE, Hooper AM, Pelxoto AA Soares MJ: Pheromone Gland Development and Pheromone Production in Lutzomyia longipalpis (Diptera: Psychodidae: Phlebotominae). J Med Entomol 2011, 48(3):489-495.

9. Spiegel CN, Brazil RP, Soares MJ: Ultrastructure of male sex pheromone glands in abdominal tergites of five Lutzomyia sandfly species (Diptera: Psychodidae). Arthropod Struct Dev 2002, 30(3):219-227.

10. Ward R, Hamilton J, Dougherty M, Falcão A, Feliciangeli M, Perez J, Veltkamp C: Pheromone disseminating structures in tergites of male phlebotomines (Diptera: Psychodidae). Bull Entomol Res 1993, 83:437-445.

11. Lanzaro GC, Ostrovska K, Herrero MV, Lawyer PG, Warburg A: Lutzomyia longipalpis is a species complex: genetic divergence and interspecific hybrid sterility among three populations. AmJ Trop Med Hyg 1993, 48(6):839-847.

12. Uribe $\mathrm{S}$ : The status of the Lutzomyia longipalpis species complex and possible implications for Leishmania transmission. Mem Inst Oswaldo Cruz 1999, 94:729-734.

13. Arrivillaga J, Mutebi JP, Piñango $H$, Norris D, Alexander B, Feliciangeli MD, Lanzaro GC: The taxonomic status of genetically divergent populations of Lutzomyia longipalpis (Diptera: Psychodidae) based on the distribution of mitochondrial and isozyme variation. J Med Entomol 2003, 40(5):615-627.

14. Bauzer LGSR, Souza NA, Maingon RDC, Peixoto AA: Lutzomyia longipalpis in Brazil: a complex or a single species? A mini-review. Mem Inst Oswaldo Cruz 2007, 102(1):1-12.

15. Maingon RDC, Ward RD, Hamilton JGC, Bauzer LGSR, Peixoto AA: The Lutzomyia longipalpis species complex: does population sub-structure matter to Leishmania transmission? Trends Parasitol 2008, 24(1):12-17.

16. Hamilton JG, Maingon RD, Alexander B, Ward RD, Brazil RP: Analysis of the sex pheromone extract of individual male Lutzomyia longipalpis sandflies from six regions in Brazil. Med Vet Entomol 2005, 19(4):480-488.

17. Hamilton JGC, Ibbotson HC, Hooper AM, Pickett JA: 9-Methylgermacrene-B is confirmed as the sex pheromone of the sandfly Lutzomyia longipalpis from Lapinha, Brazil, and the absolute stereochemistry defined as $\mathrm{S}$. Chem Commun 1999, 23:2335-2336.

18. Hamilton JG: Sandfly pheromones. Their biology and potential for use in control programs. Parasite (Paris, France) 2008, 15(3):252-256.

19. Hamilton JGC, Dawson GW, Pickett JA: 3-Methyl-a-himachalene: Proposed structure for novel homosesquiterpene sex pheromone of Lutzomyia longipalpis (diptera: Psychodidae) from Jacobina, Brazil. J Chem Ecol 1996, 22(12):2331-2340
20. Hamilton JG, Brazil RP, Maingon R: A fourth chemotype of Lutzomyia longipalpis (Diptera: Psychodidae) from Jaibas, Minas Gerais State, Brazil. J Med Entomol 2004, 41(6):1021-1026.

21. Bray D, Ward R, Hamilton J: The chemical ecology of sandflies. In Olfaction in vector-host interactions. Volume 2. Edited by Takken W, Knols B. The Netherland: Wageningen Academic Publishers; 2010:203-215.

22. Ward RD, Hamilton JG, Dougherty M, Falcao AL: Pheromones in Old and New World sandflies (Diptera: Psychodidae). Ann Trop Med Parasitol 1991, 85(6):667-668.

23. Chelbi I, Bray DP, Hamilton JG: Courtship behaviour of Phlebotomus papatasi the sand fly vector of cutaneous leishmaniasis. Parasit Vectors 2012, 5:179.

24. Chelbi I, Zhioua E, Hamilton JG: Behavioral evidence for the presence of a sex pheromone in male Phlebotomus papatasi scopoli (Diptera: Psychodidae). J Med Entomol 2011, 48(3):518-525.

25. Langenheim JH: Higher plant terpenoids: a phytocentric overview of their ecological roles. J Chem Ecol 1994, 20(6):1223-1280.

26. Cane DE: Isoprenoid Biosynthesis: Overview. In Comprehensive Natural Products Chemistry, Volume 2. Oxford: Pergamon Press; 1999:1-13.

27. Goldstein JL, Brown MS: Regulation of the mevalonate pathway. Nature 1990, 343(6257):425.

28. Eisenreich W, Bacher A, Arigoni D, Rohdich F: Biosynthesis of isoprenoids via the non-mevalonate pathway. Cell Mol Life Sci 2004, 61(12):1401-1426.

29. Bochar DA, Freisen J, Stauffacher CV, Rodwell WW, Otto M-C, Sir Derek B, Koji $\mathrm{N}$ : Biosynthesis of Mevalonic Acid from Acetyl-CoA. In Comprehensive Natural Products Chemistry. Oxford: Pergamon; 1999:15-44.

30. Bellés $X$, Martin D, Piulachs MD: The mevalonate pathway and the synthesis of juvenile hormone in insects. Annu Rev Entomol 2005, 50:181-199.

31. Blomquist GJ, Figueroa-Teran R, Aw M, Song M, Gorzalski A, Abbott NL, Chang E, Tittiger C: Pheromone production in bark beetles. Insect Biochem Mol Biol 2010, 40(10):699-712.

32. Nürenberg G, Volmer DA: The analytical determination of isoprenoid intermediates from the mevalonate pathway. Anal Bioanal Chem 2012, 402(2):671-685.

33. Ogura K, Koyama T: Enzymatic aspects of isoprenoid chain elongation Chem Rev 1998, 98(4):1263-1276.

34. Sen SE, Cusson M, Trobaugh C, Beliveau C, Richard T, Graham W, Mimms A, Roberts G: Purification, properties and heteromeric association of type-1 and type-2 lepidopteran farnesyl diphosphate synthases. Insect Biochem Mol Biol 2007, 37(8):819-828

35. Kinjoh T, Kaneko Y, Itoyama K, Mita K, Hiruma K, Shinoda T: Control of juvenile hormone biosynthesis in Bombyx mori: cloning of the enzymes in the mevalonate pathway and assessment of their developmental expression in the corpora allata. Insect Biochem Mol Biol 2007, 37(8):808-818.

36. Sen SE, Trobaugh C, Béliveau C, Richard T, Cusson M: Cloning, expression and characterization of a dipteran farnesyl diphosphate synthase. Insect Biochem Mol Biol 2007, 37(11):1198-1206.

37. Vandermoten $S$, Charloteaux B, Santini S, Sen SE, Béliveau C, Vandenbol M, Francis F, Brasseur R, Cusson M, Haubruge É: Characterization of a novel aphid prenyltransferase displaying dual geranyl/farnesyl diphosphate synthase activity. FEBS Lett 2008, 582(13):1928-1934.

38. Zhang YL, Li ZX: Two different farnesyl diphosphate synthase genes exist in the genome of the green peach aphid, Myzus persicae. Genome 2008, 51(7):501-510.

39. Gilg AB, Bearfield JC, Tittiger C, Welch WH, Blomquist GJ: Isolation and functional expression of an animal geranyl diphosphate synthase and its role in bark beetle pheromone biosynthesis. Proc Natl Acad Sci USA 2005, 102(28):9760-9765.

40. Lewis MJ, Prosser IM, Mohib A, Field LM: Cloning and characterisation of a prenyltransferase from the aphid Myzus persicae with potential involvement in alarm pheromone biosynthesis. Insect Mol Biol 2008, 17(4):437-443.

41. Morgan D: Biosynthesis in Insects. Great Britain: Royal Society of Chemistry; 2010

42. Strandh M, Johansson T, Ahrén D, Löfstedt C: Transcriptional analysis of the pheromone gland of the turnip moth, Agrotis segetum (Noctuidae), reveals candidate genes involved in pheromone production. Insect $\mathrm{Mol}$ Biol 2008, 17(1):73-85.

43. Vogel H, Heidel AJ, Heckel DG, Groot AT: Transcriptome analysis of the sex pheromone gland of the noctuid moth Heliothis virescens. BMC Genomics 2010, 11:29.

44. Hojo M, Maekawa K, Saitoh S, Shigenobu S, Miura T, Hayashi Y, Tokuda G, Maekawa $\mathrm{H}$ : Exploration and characterization of genes involved in the synthesis of diterpene defence secretion in nasute termite soldiers. Insect Mol Biol 2012, 21(6):545-557. 
45. Dillon RJ, Ivens AC, Churcher C, Holroyd N, Quail MA, Rogers ME, Soares MB, Bonaldo MF, Casavant TL, Lehane MJ, et al: Analysis of ESTs from Lutzomyia longipalpis sand flies and their contribution toward understanding the insect-parasite relationship. Genomics 2006, 88(6):831-840

46. Anderson JM, Oliveira F, Kamhawi S, Mans BJ, Reynoso D, Seitz AE, Lawyer P, Garfield M, Pham MV, Valenzuela JG: Comparative salivary gland transcriptomics of sandfly vectors of visceral leishmaniasis. BMC Genomics 2006, 7(1):52

47. Jochim R, Teixeira C, Laughinghouse A, Mu J, Oliveira F, Gomes R, Elnaiem $D E$, Valenzuela J: The midgut transcriptome of Lutzomyia longipalpis: comparative analysis of cDNA libraries from sugar-fed, blood-fed, postdigested and Leishmania infantum chagasi-infected sand flies. BMC Genomics 2008, 9(1):15

48. Pitaluga AN, Beteille V, Lobo AR, Ortigao-Farias JR, Davila AM, Souza AA, Ramalho-Ortigao JM, Traub-Cseko YM: EST sequencing of blood-fed and Leishmania-infected midgut of Lutzomyia longipalpis, the principal visceral leishmaniasis vector in the Americas. Mol Genet Genomics 2009, 282(3):307-317.

49. Azevedo RV, Dias DB, Bretas JA, Mazzoni CJ, Souza NA, Albano RM, Wagner G, Davila AM, Peixoto AA: The Transcriptome of Lutzomyia longipalpis (Diptera: Psychodidae) Male Reproductive Organs. PLOS One 2012, 7(3):e34495.

50. Brazil RP, Brazil BG: Biologia de Flebotomíneos Tropicais. In Flebotomíneos do Brasil. Edited by Rangel E, Lainson R. Rio de Janeiro: Editora Fiocruz; 2003:257-274.

51. Valenzuela JG, Pham VM, Garfield MK, Francischetti IMB, Ribeiro JMC: Toward a description of the sialome of the adult female mosquito Aedes aegypti. Insect Biochem Mol Biol 2002, 32(9):1101-1122.

52. Francischetti I, Anderson JM, Manoukis N, Pham VM, Ribeiro J: An insight into the sialotranscriptome and proteome of the coarse bontlegged tick, Hyalomma marginatum rufipes. J Proteomics 2011, 74(12):2892-2908.

53. Huang X, Madan A: CAP3: A DNA sequence assembly program. Genome Res 1999, 9(9):868-877.

54. Valenzuela JG, Francischetti I, Pham VM, Garfield MK, Ribeiro J: Exploring the salivary gland transcriptome and proteome of the Anopheles stephensi mosquito. Insect Biochem Mol Biol 2003, 33(7):717-732.

55. Ashburner M, Ball CA, Blake JA, Botstein D, Butler H, Cherry JM, Davis AP, Dolinski K, Dwight SS, Eppig JT: Gene Ontology: tool for the unification of biology. Nat Genet 2000, 25(1):25

56. Wheeler DL, Barrett T, Benson DA, Bryant SH, Canese K, Church DM, DiCuccio M, Edgar R, Federhen S, Helmberg W: Database resources of the national center for biotechnology information. Nucleic Acids Res 2005, 33(suppl 1):D39-D45.

57. Bateman A, Birney E, Durbin R, Eddy SR, Howe KL, Sonnhammer ELL: The Pfam protein families database. Nucleic Acids Res 2000, 28(1):263-266.

58. Schultz J, Copley RR, Doerks T, Ponting CP, Bork P: SMART: a web-based tool for the study of genetically mobile domains. Nucleic Acids Res 2000, 28(1):231-234

59. Tatusov RL, Fedorova ND, Jackson JD, Jacobs AR, Kiryutin B, Koonin EV Krylov DM, Mazumder R, Mekhedov SL, Nikolskaya AN: The COG database: an updated version includes eukaryotes. BMC Bioinforma 2003, 4(1):41.

60. Kumar S, Tamura K, Nei M: MEGA3: integrated software for molecular evolutionary genetics analysis and sequence alignment. Brief Bioinform 2004, 5(2):150-163.

61. Keeling Cl, Henderson H, Li M, Yuen M, Clark EL, Fraser JD, Huber DPW, Liao NY, Docking TR, Birol I: Transcriptome and full-length CDNA resources for the mountain pine beetle, Dendroctonus ponderosae Hopkins, a major insect pest of pine forests. Insect Biochem Mol Biol 2012, 42(8):525-536.

62. Keeling C, Blomquist G, Tittiger C: Coordinated gene expression for pheromone biosynthesis in the pine engraver beetle, Ips pini (Coleoptera: Scolytidae). Naturwissenschaften 2004, 91(7):324-328.

63. Kanehisa M, Goto S, Sato Y, Furumichi M, Tanabe M: KEGG for integration and interpretation of large-scale molecular data sets. Nucleic Acids Res 2012, 40(Database issue):D109-D114. http://www.genome.jp/kegg/pathway/ map/map00900.html.

64. Bochar DA, Stauffacher CV, Rodwell W: Sequence comparisons reveal two classes of 3-hydroxy-3-methylglutaryl coenzyme A reductase. Mol Genet Metab 1999, 66(2):122-127.

65. Hampton R, Dimster-Denk D, Rine J: The biology of HMG-CoA reductase: the pros of contra-regulation. Trends Biochem Sci 1996, 21(4):140

66. Taban AH, Fu J, Blake J, Awano A, Tittiger C, Blomquist GJ: Site of pheromone biosynthesis and isolation of HMG-CoA reductase CDNA in the cotton boll weevil, Anthonomus grandis. Arch Insect Biochem Physiol 2006, 62(4):153-163.

67. Ivarsson P, Tittiger C, Blomquist C, Borgeson CE, Seybold SJ, Blomquist GJ, Högberg HE: Pheromone precursor synthesis is localized in the metathorax of Ips paraconfusus Lanier (Coleoptera: Scolytidae). Naturwissenschaften 1998, 85(10):507-511.

68. Hall GM, Tittiger C, Andrews GL, Mastick GS, Kuenzli M, Luo X, Seybold SJ, Blomquist GJ: Midgut tissue of male pine engraver, Ips pini, synthesizes monoterpenoid pheromone component ipsdienol de novo. Die Naturwissenschaften 2002, 89(2):79-83.

69. Hall GM, Tittiger C, Blomquist GJ, Andrews GL, Mastick GS, Barkawi LS, Bengoa C, Seybold SJ: Male jeffrey pine beetle, Dendroctonus jeffreyi, synthesizes the pheromone component frontalin in anterior midgut tissue. Insect Biochem Mol Biol 2002, 32(11):1525-1532.

70. Nardi J, Young AG, Ujhelyi E, Tittiger C, Lehane M, Blomquist G: Specialization of midgut cells for synthesis of male isoprenoid pheromone components in two scolytid beetles, Dendroctonus jeffreyi and Ips pini. Tissue Cell 2002, 34(4):221-231.

71. Herdendorf TJ, Miziorko HM: Phosphomevalonate kinase: functional investigation of the recombinant human enzyme. Biochemistry 2006 45(10):3235-3242

72. Miziorko HM: Enzymes of the mevalonate pathway of isoprenoid biosynthesis. Arch Biochem Biophys 2011, 505(2):131-143.

73. Herdendorf TJ, Miziorko HM: Functional evaluation of conserved basic residues in human phosphomevalonate kinase. Biochemistry 2007 46(42):11780-11788.

74. Berges T, Guyonnet D, Karst F: The Saccharomyces cerevisiae mevalonate diphosphate decarboxylase is essential for viability, and a single Leu-to-Pro mutation in a conserved sequence leads to thermosensitivity. J Bacteriol 1997, 179(15):4664-4670.

75. Bloch K, Chaykin S, Phillips AH, De Waard A: Mevalonic acid pyrophosphate and isopentenylpyrophosphate. J Biol Chem 1959, 234(10):2595-2604

76. Eigenheer $\mathrm{AL}$, Keeling $\mathrm{Cl}$, Young $\mathrm{S}$, Tittiger $\mathrm{C}$ : Comparison of gene representation in midguts from two phytophagous insects, Bombyx mori and Ips pini, using expressed sequence tags. Gene 2003, 316:127-136.

77. Berthelot K, Estevez Y, Deffieux A, Peruch F: Isopentenyl diphosphate isomerase: A checkpoint to isoprenoid biosynthesis. Biochimie 2012, 94(8):1621-1634.

78. Vandermoten S, Haubruge E, Cusson M: New insights into short-chain prenyltransferases: structural features, evolutionary history and potential for selective inhibition. Cell Mol Life Sci 2009, 66(23):3685-3695.

79. Taban $\mathrm{AH}$, Tittiger $\mathrm{C}$, Blomquist $\mathrm{GJ}$, Welch WH: Isolation and characterization of farnesyl diphosphate synthase from the cotton boll weevil, Anthonomus grandis. Arch Insect Biochem Physiol 2009, 71(2):88-104.

80. Vandermoten $S$, Santini $S$, Haubruge $E$, Heuze F, Francis F, Brasseur R Cusson M, Charloteaux B: Structural features conferring dual geranyl/ farnesyl diphosphate synthase activity to an aphid prenyltransferase. Insect Biochem Mol Biol 2009, 39(10):707-716.

81. Ma GY, Sun XF, Zhang YL, Li ZX, Shen ZR: Molecular cloning and characterization of a prenyltransferase from the cotton aphid, Aphis gossypii. Insect Biochem Mol Biol 2010, 40(7):552-561.

82. Castillo Gracia M, Couillaud F: Molecular cloning and tissue expression of an insect farnesyl diphosphate synthase. Eur J Biochem 1999, 262(2):365370 .

83. Kikuchi K, Hirai M, Shiotsuki T: Molecular cloning and tissue distribution of farnesyl pyrophosphate synthase from the silkworm Bombyx mori. J Insect Biotechnol Sericol 2001, 70(3):167-172.

84. Cusson M, Béliveau C, Sen SE, Vandermoten S, Rutledge RG, Stewart D, Francis F, Haubruge É, Rehse P, Huggins DJ, et al: Characterization and tissue-specific expression of two lepidopteran farnesyl diphosphate synthase homologs: Implications for the biosynthesis of ethylsubstituted juvenile hormones. Proteins 2006, 65(3):742-758.

85. Zhang Y-L, Li Z-X: Functional analysis and molecular docking identify two active short-chain prenyltransferases in the green peach aphid, Myzus persicae. Arch Insect Biochem Physiol 2012, 81(2):63-76.

86. Keeling $\mathrm{Cl}$, Blomquist GJ, Tittiger C: Coordinated gene expression for pheromone biosynthesis in the pine engraver beetle, Ips pini (Coleoptera: Scolytidae). Die Naturwissenschaften 2004, 91(7):324-328.

87. Ashby MN, Edwards PA: Elucidation of the deficiency in two yeast coenzyme $\mathrm{Q}$ mutants. Characterization of the structural gene encoding hexaprenyl pyrophosphate synthetase. J Biol Chem 1990, 265(22):13157-13164. 
88. Ohnuma S, Hirooka K, Ohto C, Nishino T: Conversion from archaeal geranylgeranyl diphosphate synthase to farnesyl diphosphate synthase. J Biol Chem 1997, 272(8):5192-5198.

89. Mayoral JG, Nouzova M, Navare A, Noriega FG: NADP + -dependent farnesol dehydrogenase, a corpora allata enzyme involved in juvenile hormone synthesis. Proc Natl Acad Sci 2009, 106(50):21091-21096.

90. Perssom B, Krook M, Jörvall H: Characteristics of short--chain alcohol dehydrogenases and related enzymes. Eur J Biochem 2005, 200(2):537-543.

91. Hekmat-Scafe DS, Dorit RL, Carlson JR: Molecular evolution of odorantbinding protein genes OS-E and OS-F in Drosophila. Genetics 2000, 155(1):117-127.

92. Wanner KW, Willis LG, Theilmann DA, Isman MB, Feng Q, Plettner E: Analysis of the insect os-d-like gene family. J Chem Ecol 2004, 30(5):889-911.

93. Dani FR, Michelucci E, Francese S, Mastrobuoni G, Cappellozza S, La Marca G, Niccolini A, Felicioli A, Moneti G, Pelosi P: Odorant-binding proteins and chemosensory proteins in pheromone detection and release in the silkmoth Bombyx mori. Chem Senses 2011, 36(4):335-344

94. Jacquin-Joly E, Vogt RG, Francois MC, Nagnan-Le Meillour P: Functional and expression pattern analysis of chemosensory proteins expressed in antennae and pheromonal gland of Mamestra brassicae. Chem Senses 2001, 26(7):833-844.

95. Zhou JJ, Kan Y, Antoniw J, Pickett JA, Field LM: Genome and EST analyses and expression of a gene family with putative functions in insect chemoreception. Chem Senses 2006, 31(5):453-465.

96. Goodman W, Gilbert L: Hemolymph protein binding of juvenile hormone in Manduca sexta. Am Zool 1974, 14:1289.

97. Hidayat P, Goodman WG: Juvenile hormone and hemolymph juvenile hormone binding protein titers and their interaction in the hemolymph of fourth stadium Manduca sexta. Insect Biochem Mol Biol 1994, 24(7):709-715.

98. Tillman JA, Holbrook GL, Dallara PL, Schal C, Wood DL, Blomquist GJ, Seybold SJ: Endocrine regulation of de novo aggregation pheromone biosynthesis in the pine engraver, Ips pini (Say)(Coleoptera: Scolytidae). Insect Biochem Mol Biol 1998, 28(9):705-715.

99. Tillman JA, Seybold SJ, Jurenka RA, Blomquist GJ: Insect pheromones-an overview of biosynthesis and endocrine regulation. Insect Biochem Mol Biol 1999, 29(6):481-514.

100. Rafaeli A, Jurenka RA: PBAN regulation of pheromone biosynthesis in female moths. In Insect Pheromone Biochemistry and Molecular Biology. Edited by Gary B, Richard V. San Diego: Academic Press; 2003:107-136.

101. Jurenka R: Insect Pheromone Biosynthesis. In The Chemistry of Pheromones and Other Semiochemicals I. 239th edition. Edited by Schulz S. Berlin: Springer Berlin Heidelberg; 2004:97-132.

102. Feyereisen R: Insect P450 enzymes. Annu Rev Entomol 1999, 44(1):507-533.

103. Berenbaum MR: Postgenomic chemical ecology: from genetic code to ecological interactions. J Chem Ecol 2002, 28(5):873-896.

104. Schuler MA: The role of cytochrome P450 monooxygenases in plantinsect interactions. Plant Physiol 1996, 112(4):1411.

105. Wen Z, Pan L, Berenbaum MR, Schuler MA: Metabolism of linear and angular furanocoumarins by Papilio polyxenes CYP6B1 co-expressed with NADPH cytochrome P450 reductase. Insect Biochem Mol Biol 2003, 33(9):937-947.

106. Wadleigh RW, Yu SJ: Glutathione transferase activity of fall armyworm larvae toward $a, \beta$-unsaturated carbonyl allelochemicals and its induction by allelochemicals. Insect Biochem 1987, 17(5):759-764.

107. Robertson H, Martos R, Sears C, Todres E, Walden K, Nardi J: Diversity of odourant binding proteins revealed by an expressed sequence tag project on male Manduca sexta moth antennae. Insect Mol Biol 1999, 8(4):501-518.

108. De Kort CAD, Granger NA: Regulation of JH titers: the relevance of degradative enzymes and binding proteins. Arch Insect Biochem Physiol 1996, 33(1):1-26.

109. Picimbon JF: Biochemistry and evolution of OSD and OBP proteins. In Insect Pheromone Biochemistry and Molecular Biology. New edition. Edited by Blomquist G, Vogt RG. USA: NY Academic Press; 2003:539-566.

doi:10.1186/1756-3305-6-56

Cite this article as: González-Caballero et al:: Transcriptome exploration of the sex pheromone gland of Lutzomyia longipalpis (Diptera: Psychodidae: Phlebotominae). Parasites \& Vectors 2013 6:56.

\section{Submit your next manuscript to BioMed Central and take full advantage of:}

- Convenient online submission

- Thorough peer review

- No space constraints or color figure charges

- Immediate publication on acceptance

- Inclusion in PubMed, CAS, Scopus and Google Scholar

- Research which is freely available for redistribution 